\title{
HIV-1 envelope replication and a4ß7 utilization among newly infected subjects and their corresponding heterosexual partners
}

\author{
Victor Pena-Cruz ${ }^{1 \dagger}$, Behzad Etemad $^{1 \dagger}$, Nikolaos Chatziandreou $^{1}$, Phyu Hninn Nyein ${ }^{1}$, Shannon Stock ${ }^{2}$, \\ Steven J Reynolds ${ }^{3,4}$, Oliver Laeyendecker ${ }^{3,4}$, Ronald H Gray ${ }^{5}$, David Serwadda ${ }^{6}$, Sandra J Lee, \\ Thomas C Quinn ${ }^{3,4}$ and Manish Sagar ${ }^{1,8^{*}}$
}

\begin{abstract}
Background: Previous studies suggest that active selection limits the number of HIV-1 variants acquired by a newly infected individual from the diverse variants circulating in the transmitting partner. We compared HIV-1 envelopes from 9 newly infected subjects and their linked transmitting partner to explore potential mechanisms for selection.

Results: Recipient virus envelopes had significant genotypic differences compared to those present in the transmitting partner. Recombinant viruses incorporating pools of recipient and transmitter envelopes showed no significant difference in their sensitivity to receptor and fusion inhibitors, suggesting they had relatively similar entry capacity in the presence of low CD4 and CCR5 levels. Aggregate results in primary cells from up to 4 different blood or skin donors showed that viruses with envelopes from the transmitting partner as compared to recipient envelopes replicated more efficiently in CD4+ T cells, monocyte derived dendritic cell (MDDC) - CD4+ T cell co-cultures, Langerhans cells (LCs) - CD4+ T cell co-cultures and CD4+ T cells expressing high levels of the gut

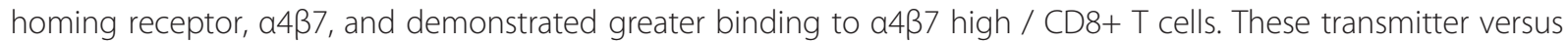
recipient envelope virus phenotypic differences, however, were not always consistent among the primary cells from all the different blood or skin donation volunteers.
\end{abstract}

Conclusion: Although genotypically unique variants are present in newly infected individuals compared to the diverse swarm circulating in the chronically infected transmitting partner, replication in potential early target cells and receptor utilization either do not completely dictate this genetic selection, or these potential transmission phenotypes are lost very soon after HIV-1 acquisition.

Keywords: HIV-1, Envelope, Transmission, Receptor, Replication, Alpha4 beta7, Dendritic cells, Langerhans cells, Selection

\section{Background}

Landmark studies more than 20 years ago demonstrated that newly infected subjects often harbor a limited number of HIV-1 variants early after virus acquisition [1-3]. Subsequent studies further showed that naïve individuals are often infected with a single or multiple variants, and

\footnotetext{
* Correspondence: msagar@bu.edu

${ }^{\dagger}$ Equal contributors

'Department of Medicine, Division of Infectious Diseases, Boston University, Boston, MA, USA

${ }^{8}$ Boston University, Evans Biomedical Research Building, 650 Albany Street, Room 647, Boston, MA 02118-2518, USA

Full list of author information is available at the end of the article
}

the complexity of the early virus population is influenced by factors present at the time of acquisition, such as genital tract inflammation [4-7]. More recent studies have robustly estimated both the number and the characteristics of the strains present early after infection [8-14]. In aggregate, these diverse studies demonstrate that even though chronically infected individuals harbor a large array of variants, only a small number of viruses with specific characteristics are able to successfully establish a persistent systemic infection in a naïve host.

The biological mechanisms underlying this observed bottleneck during transmission remain undefined. Because 
the acquired viruses in the newly infected subject often do not cluster among the major variants present in the transmitting partner, stochastic mechanisms likely do not account for the genetic restriction observed during transmission [15]. Genotypic and phenotypic studies show that the acquired variants predominantly utilize the CCR5 coreceptor and contain signature envelope genotypes, such as shorter and less glycosylated envelope variable loops that are more closely related to ancestral strains [11-13,16-20]. In aggregate, these studies suggest that specific viruses with unique characteristics are favored for transmission from the quasispecies present in the transmitting partner.

Identifying the virus property that confers fitness during transmission has been a high priority within the field because this understanding may foster the development of targeted interventions to prevent acquisition. Because variants with shorter and less glycosylated envelopes were enriched among the virus populations sampled early after infection, it was hypothesized that transmitted viruses may have more exposed receptor binding sites leading to enhanced receptor utilization and higher replication capacity. Envelopes from viruses found early after infection or the inferred transmitted/founder (T/F) viruses, however, have not demonstrated an enhanced ability to utilize low CD4 or CCR5 levels or a higher capacity to enter cells compared to the envelopes from the variants present in the corresponding transmitting partner or those present during the chronic stage of disease [21-26]. These previous studies have often used virus pseudotypes to investigate potential transmission phenotypes. Pseudoviruses cannot be used to probe virus replication in the target cells present at the site of invasion as a potential phenotype that confers fitness during transmission. One recent study showed that full-length T/F strains replicated significantly more efficiently compared to unrelated chronic stage variants [27]. Selection of a relatively small number of unrelated chronic stage variants, however, may have biased this comparison. Thus, the previous studies have not adequately examined replication capacity differences in potential early target cells among envelopes isolated from transmission linked partners.

Besides infection capacity in early target cells, a variants' ability to disseminate from the initial site of invasion could also potentially influence the observed genetic restriction during HIV-1 acquisition. After HIV-1 establishes a beachhead in a new host, the virus cannot be detected in the systemic circulation for a number of days [28-30]. During this silent phase, the virus presumably replicates at the local site of invasion and then migrates to gut associated lymphoid tissue (GALT). Systemic dissemination early after acquisition is associated with high level replication within GALT [31]. Newer studies speculate that binding to the $\alpha 4 \beta 7$ integrin may play a crucial role in the migration of the virus from the exposure site to GALT $[32,33]$. Interestingly, HIV-1 envelope glycoprotein subunits with characteristics associated with newly acquired viruses demonstrate high binding to $\alpha 4 \beta 7+$ cells, and this attachment decreased with envelope modifications observed over the course of infection suggesting that this may be a highly transient transmission phenotype [34].

In this study, we generated replication competent recombinant viruses incorporating pooled HIV-1 envelopes isolated from 9 recently infected individuals and their corresponding heterosexual partner in Rakai, Uganda. We compared replication in potential early target cells, coreceptor tropism, receptor utilization efficiency, and fusion capacity among viruses with HIV-1 envelope glycoproteins isolated from these transmission pairs. By comparing genotypic and phenotypic features among viruses found in newly infected subjects compared to those present in the transmitting partner, our studies provide new insights for the biological mechanisms for the genetic selection during transmission.

\section{Results}

\section{Couples and envelope sequences}

We retrospectively identified 8 couples from the Rakai Couple Cohort Study (RCCS) in which the newly infected subject was sampled prior to HIV-1 seroconversion. We were successfully able to amplify full-length envelopes from 9 of the 16 individuals in these partnerships. In 2 couples envelopes were amplified from both the newly infected recipient and the transmitting partner, and in 5 couples envelopes were successfully generated from only 1 of the 2 partners. Surprisingly, we were unable to amplify full-length envelopes in five seronegative subjects even though they had HIV-1 RNA levels greater than 100,000 copies $/ \mathrm{ml}$. To increase the number of couples, we also retrospectively identified 12 other couples in whom the newly infected subject was sampled within a year after estimated infection. Transmitter and recipient envelopes were successfully amplified from both partners in 8 couples. In the remaining partnerships, envelopes were either amplified from 1 of the 2 partners $(n=3)$ or in none of the individuals $(n=1)$. Various different primer combinations failed to yield full-length envelope PCR product in the unsuccessful cases.

Amplified product from a minimum of 4 independent bulk PCRs were pooled to minimize resampling bias [35]. Pooled envelope products were cloned into a HIV-1 NL43 backbone using yeast gap-repair homologous recombination [36]. From each subject, full-length envelope sequences were examined from 8 to 12 different clones. Phylogenetic analysis incorporating reference sequences and other previously isolated full-length envelope sequences from the RCCS confirmed the epidemiological 
partnership in 9 of the 10 couples (Figure 1). Recipient and transmitter sequences failed to cluster in one of the epidemiologically linked couples suggesting that the newly infected partner acquired HIV-1 from outside the partnership (data not shown). Further genotypic and phenotypic analysis was continued in 9 couples with the confirmed sequence linkage (Table 1) (Figure 1). The 9 couples examined in this study were all infected with subtype D HIV-1. The newly infected partner in these nine couples was sampled a median of 70 days (range 17 - 324 days) after estimated infection. Longitudinal follow up in the Rakai cohort suggested that the transmitting partner had been infected for a minimum of 2 years prior to transmission to the newly infected recipient. Concurrent samples were obtained from each partner a median of 19 days (range $0-46$ days) apart. If early host pressure selects against viruses harboring a property that confers fitness for transmission, we hypothesized that variants isolated within 3 months to 1 year after estimated acquisition should be relatively similar to the viruses circulating in the chronically infected transmitter. Thus, observing differences among recipient transmitter envelope properties could still yield important information even though the majority of the recently infected individuals were not sampled relatively soon after estimated acquisition.

In thirteen couples from the RCCS, we had previously shown that a limited number of minority variants closely related to the ancestral sequences were preferentially acquired by a naïve subject from the variants present in the transmitter [12]. Adding the nine couples to the previous thirteen reported partnerships, we confirmed that sequences present in the newly infected subject compared to those in the transmitter had a significantly shorter distance to the estimated most recent common ancestor (MRCA) (median ratio of recipient versus transmitter sequences' distance to MRCA 0.82, range

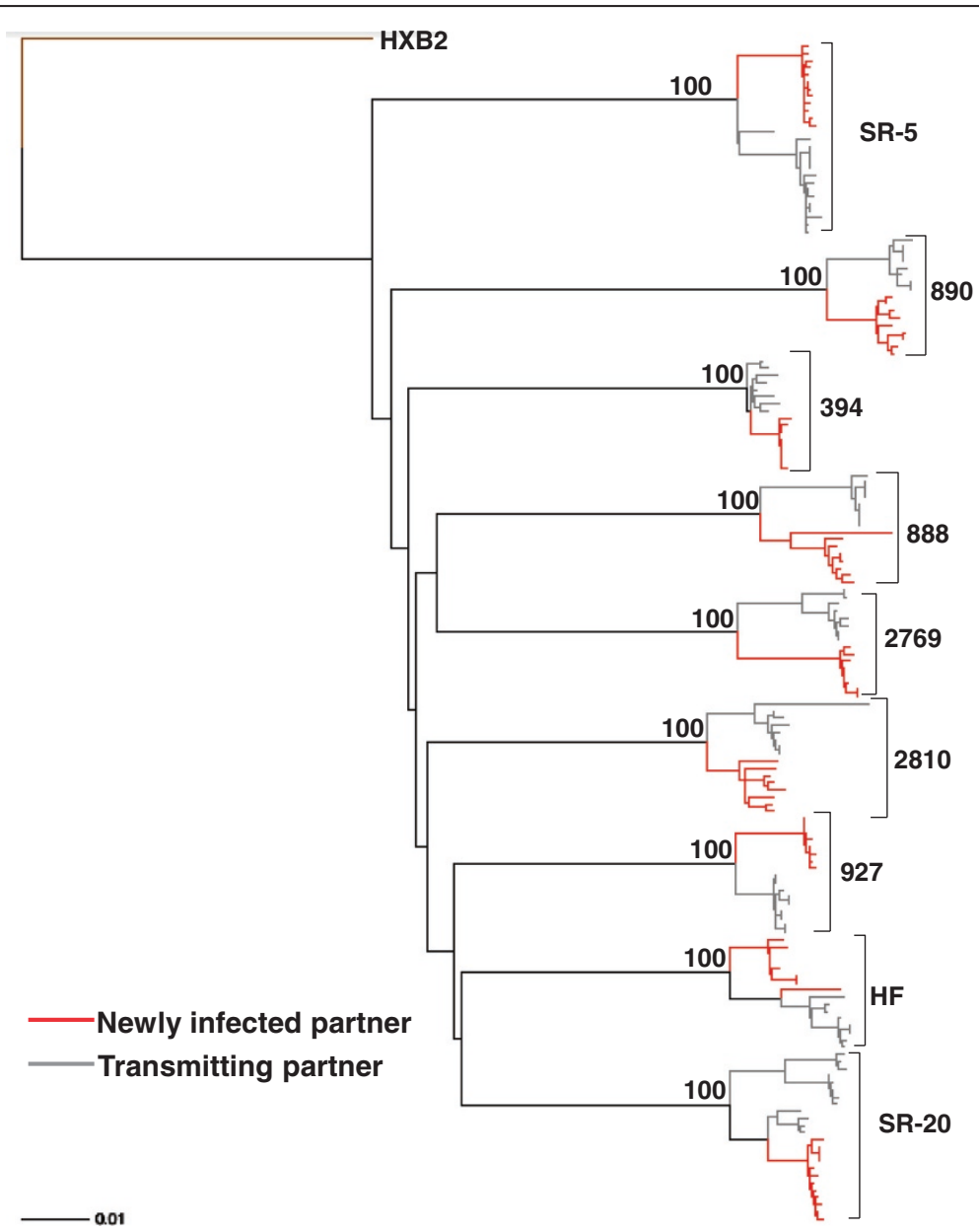

Figure 1 Epidemiologically linked partner's HIV-1 envelope sequences are phylogenetically linked. Full-length HIV-1 envelope transmitter (gray) and recipient (red) sequences were aligned with subtype reference sequences from the Los Alamos database using Clustal X. Paup was used to generate the maximum likelihood tree using parameters from FindModel best fit evolutionary model. Bootstrap values from 100 replicates were generated from a neighbor joining tree and are noted on each node of interest. Couple IDs and HXB2 reference outgroup node are noted. 
Table 1 Demographics, viral and coreceptor characteristics

\begin{tabular}{|c|c|c|c|c|c|c|c|c|c|}
\hline Couple & Type $^{1}$ & Int. days ${ }^{2}$ & $\begin{array}{c}\text { Partner } \\
\text { interval }^{3}\end{array}$ & $\begin{array}{c}\text { Recipient } \\
\text { CCR5 }^{4}\end{array}$ & $\begin{array}{l}\text { Recipient } \\
\text { CXCR4 }^{5}\end{array}$ & $\begin{array}{l}\text { Recipient } \\
\text { tropism }^{6}\end{array}$ & $\begin{array}{l}\text { Transmitter } \\
\text { CCR5 }\end{array}$ & $\begin{array}{l}\text { Transmitter } \\
\text { CXCR4 }\end{array}$ & $\begin{array}{c}\text { Transmitter } \\
\text { tropism }\end{array}$ \\
\hline $\mathrm{HF}$ & FTM & 17 & 3 & 7.24 & $<0.1$ & R5 & 8.27 & $<0.1$ & R5 \\
\hline 888 & MTF & 74 & 19 & 10.39 & $<0.1$ & R5 & 11.91 & $<0.1$ & R5 \\
\hline 890 & MTF & 138 & 12 & 3.79 & $<0.1$ & R5 & 2.27 & $<0.1$ & R5 \\
\hline 394 & MTF & 93 & 2 & 7.79 & $<0.1$ & R5 & 10.85 & $<0.1$ & R5 \\
\hline 927 & MTF & 324 & 46 & 12.55 & $<0.1$ & R5 & 13.37 & $<0.1$ & R5 \\
\hline 2769 & MTF & 149 & 46 & 5.69 & $<0.1$ & R5 & 5.34 & 0.65 & $\mathrm{R} 5 / \mathrm{X} 4$ \\
\hline 2810 & MTF & 161 & 23 & 5.49 & $<0.1$ & R5 & 6.12 & $<0.1$ & R5 \\
\hline SR-5 & MTF & 17 & 0 & 12.62 & $<0.1$ & R5 & 9.72 & $<0.1$ & R5 \\
\hline SR-20 & MTF & 91 & 34 & 6.70 & $<0.1$ & R5 & 7.24 & $<0.1$ & R5 \\
\hline
\end{tabular}

${ }^{1}$ FTM: female to male; MTF: male to female.

${ }^{2}$ Interval in days from the estimated date of acquisition to the day of sample collection for the newly infected partner. For seronegative individuals, interval was estimated as a maximum of 17 days.

${ }^{3}$ Interval in days between sampling of the two partners within a couple.

${ }^{4} \mathrm{P} 24(\mathrm{ug} / \mathrm{ml})$ from U87/CD4/CCR5 cells at day 4 post-infection.

${ }^{5} \mathrm{P} 24$ (ug/ml) from U87/CD4/CCR5 cells at day 4 post-infection.

${ }^{6}$ Tropism as determined on U87/CD4+/CCR5 and U87/CD4+/CXCR4 cells.

$0.32-1.42, \mathrm{p}<0.001)$. Recipient sequences as compared to transmitter envelopes were also less genetically diverse (median ratio of recipient versus transmitter genetic diversity range 0.57, range $0.11-5.69, \mathrm{p}<0.001$ ) and were significantly less divergent (median ratio of recipient versus transmitter genetic divergence 0.39 , range 0.06 - 9.89, $\mathrm{p}<0.001)$. Recipient compared to transmitter envelopes also had significantly lower number of amino acids in the V1-V2 ((median 66 range $(57-78)$ versus 68 $(59-77) \mathrm{p}=0.014)), \mathrm{V} 1-\mathrm{V} 4$ ((median 282 range $(268-297)$ versus $284(266-298) \mathrm{p}=0.001)$ ) and V1-V5 ((median 364 range $(322-392)$ versus $368(323-393) \mathrm{p}<0.001))$. Similar to the previous results from thirteen couples, there was no significant difference in predicted Asparagine (N)linked glycosylation sites (PNGS) among the recipient and transmitter sequences in the more comprehensive analysis of the 22 couples [12]. In addition, envelopes from the newly infected individual had significantly lower V3 loop charge (median 4, range 2-7) compared to the transmitting partners sequences (median 4, range 2-9, p < 0.001). Within each couple, there were multiple amino acids that were present at different frequencies among the recipient compared to the transmitter envelopes, but the previously identified signature pattern at HBX2 position 12 of the signal peptide was not consistently different among the partners [10]. In addition, a PNGS at HXB2 position 413-415 was also not overrepresented in the transmitting as compared to recipient partners' envelopes as described in the analysis of subtype B HIV-1 early and chronic infection sequences [10]. In aggregate, the analysis with the larger number of couples confirmed our previous finding that shorter less charged envelopes more closely related to estimated ancestral sequences were enriched during the early period after HIV-1 acquisition [12,19].

\section{Replication competent recombinant viruses and coreceptor tropism}

Previous studies have primarily examined HIV-1 envelope glycoprotein properties using 293T derived virus pseudotypes capable of a single infection cycle. We produced peripheral blood mononuclear cell (PBMC) derived virus stocks to generate replication competent viruses. Each virus stock contained pooled envelopes from a minimum of three independent cloning attempts and was generated from passage on PBMCs from 5 different donors. We confirmed that the short passage PBMC virus stocks contained similar level of envelope genotypic diversity as evident in the original clones and did not demonstrate selection sweep (Additional file 1: Figure S1). Virus titers were not significantly different among recipient (median 930 infectious particle (IP)/ul, range 15 - 18,933 $\mathrm{IP} / \mathrm{ul}$ ) compared to transmitter enveloped viruses (median $1233 \mathrm{IP} / \mathrm{ul}$, range 16 - 13,200 IP/ul, $\mathrm{p}=0.8$ ). Increased V3 loop charge as observed in the transmitter in comparison to the recipient envelopes has been associated with CXCR4 usage [37,38]. All recipient and the majority of transmitter viruses utilized the CCR5 and not the CXCR4 receptor (Table 1).

\section{Sensitivity to CD4 and CCR5 receptor and fusion blockers}

Target cells at the site of invasion potentially have low cell surface CD4 and CCR5 concentrations, and viruses with an enhanced ability to infect these cells may have an advantage during transmission [39]. We and others have shown that sensitivity to receptor blockers correlates with a virus' ability to replicate in cells with limiting receptor levels [24,40]. Viruses with a capacity to infect cells that have low receptor levels demonstrate high inhibitor $\mathrm{IC}_{50} \mathrm{~s}$, while variants that require high $\mathrm{CD} 4$ or CCR5 show low $\mathrm{IC}_{50} \mathrm{~s}$ against the receptor blocker. We 
measured sensitivity to CD4 monoclonal antibody (MAb), B4, as a surrogate for CD4 utilization [41]. All viruses were inhibited by more than $50 \%$ at the highest B4 concentration, $50 \mathrm{ug} / \mathrm{ml}$. Recipient $\mathrm{IC}_{50} \mathrm{~s}$ ranged from $0.5-9.6 \mathrm{ug} / \mathrm{ml}$ while transmitter $\mathrm{IC}_{50} \mathrm{~s}$ varied from $1.6-17.5 \mathrm{ug} / \mathrm{ml}$ (Figure 2A). In 6 of the 9 couples, transmitter as compared to the corresponding recipient envelope viruses displayed higher $\mathrm{CD} 4 \mathrm{~B} 4 \mathrm{MAb} \mathrm{IC}_{50}$ suggesting that transmitter viruses had a greater ability to utilize low CD4 receptor levels. Aggregate pair-wise comparison, however, showed no significant differences among recipient versus transmitter envelope virus sensitivity to CD4 B4 MAb $(\mathrm{p}=0.2)$.

Because newly infected subjects were sampled at various times after estimated acquisition, the isolated envelopes potentially had genetic changes that modified their phenotypic properties compared to those present in the infecting strains. To assess this possibility, we examined the correlation between the recipient versus transmitter ratio for a phenotype of interest and the duration between estimated acquisition and sampling of the newly infected subject (referred to as time post infection). A transient transmission associated phenotype would potentially display a negative linear, exponential, or polynomial relationship with time post infection. In these cases, the recipient to transmitter ratio is higher in couples where the newly infected subject was sampled relatively early after acquisition, and the ratio decreases as time post infection increases. There was a negative correlation between the ratio of recipient to transmitter $\mathrm{B} 4$ MAb $\mathrm{IC}_{50}$ and estimated days post infection $(\rho=-0.27$, $\mathrm{p}=0.49$ ), but it was not statistically significant (Figure 2D). Furthermore, the goodness of the fit was not significantly higher assuming either a polynomial or exponential decay (data not shown).

We examined sensitivity to CCR5 antagonist, Maraviroc (MVC), as a surrogate measure for the ability to enter cells expressing low CCR5 receptor concentrations. All viruses were inhibited by more than $90 \%$ at the highest MVC concentration of $25 \mathrm{nM}$. Recipient $\mathrm{IC}_{50} \mathrm{~s}$ ranged from $0.1-$ $3.3 \mathrm{nM}$ while transmitter $\mathrm{IC}_{50} \mathrm{~s}$ varied form $0.2-3.5 \mathrm{nM}$ (Figure 2B). In aggregate, there was no significant difference in MVC sensitivity among two groups of viruses $(\mathrm{p}=0.4)$. There was, however, a significant positive correlation between the recipient to transmitter ratio of Maraviroc $\mathrm{IC}_{50}$ and estimated days post infection $(\rho=$ $0.69, \mathrm{p}=0.04$ ) (Figure $2 \mathrm{E}$ ). The significant positive correlation suggests that compared to the corresponding

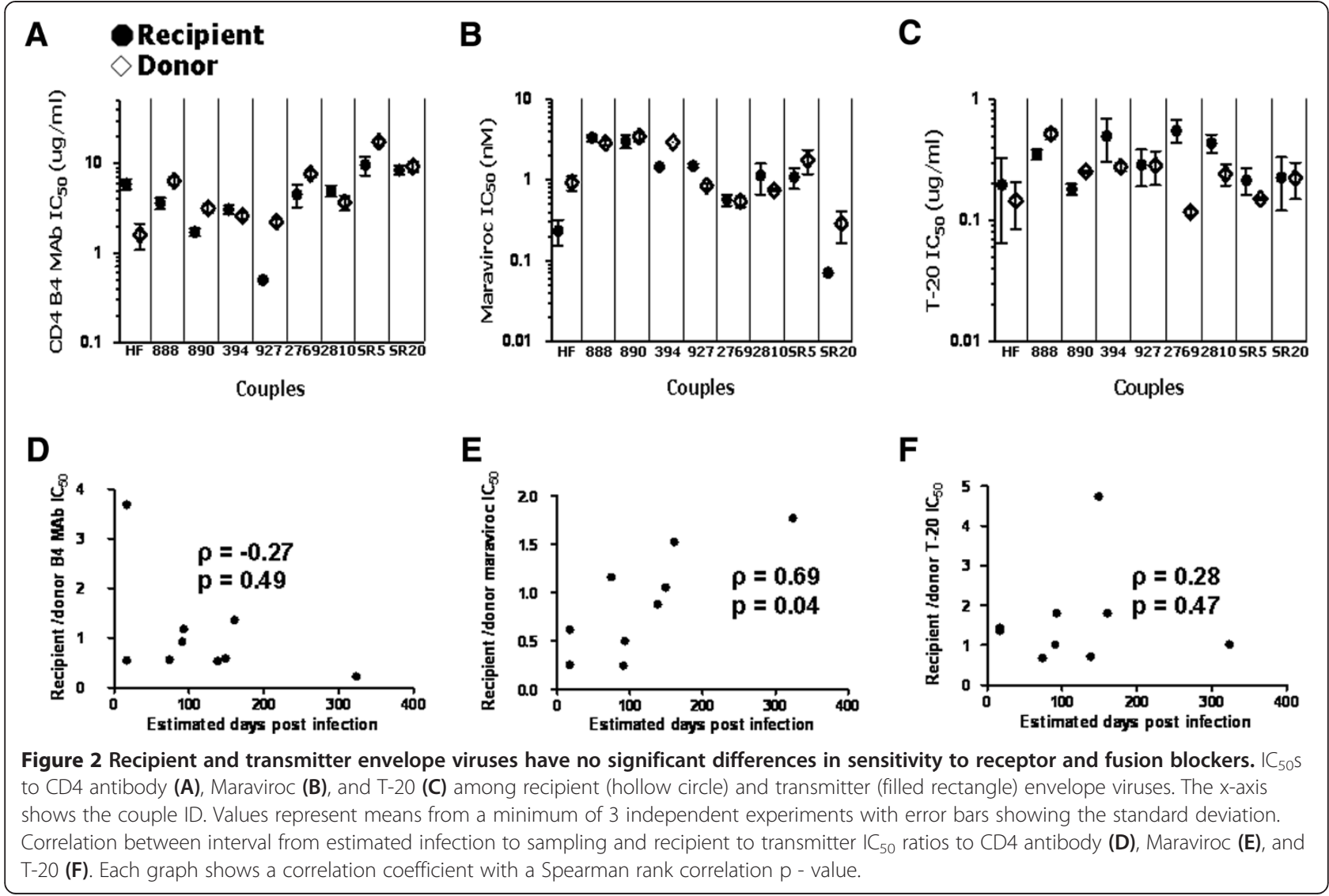


transmitting partner's envelopes the $\mathrm{MVC} \mathrm{IC}_{50}$ is lower in newly infected subjects sampled relatively early after acquisition compared to those isolated later in infection. This observation supports ours and others previous findings that viruses found early in infection require higher amounts of the CCR5 receptor for cell entry compared to those present during the chronic phase of disease $[24,36,42-46]$.

After receptor engagement, virus entry depends on fusion kinetics. Previous studies have shown that sensitivity to fusion blocker, T-20, directly correlates with fusion kinetics $[47,48]$. Highest T-20 concentration $(10 \mathrm{ug} / \mathrm{ml})$ produced around $100 \%$ cell entry block among all viruses. $\mathrm{T}-20 \mathrm{IC}_{50} \mathrm{~s}$ ranges were similar among recipient (range $0.2-0.6 \mathrm{ug} / \mathrm{ml}$ ) and transmitter (range $0.1-0.5 \mathrm{ug} / \mathrm{ml}$ ) envelope viruses. In 7 of the 9 couples, recipient as compared to the corresponding transmitter envelope viruses displayed higher $\mathrm{T}-20 \mathrm{IC}_{50}$ suggesting that viruses found in newly infected subjects had enhanced fusion, but these differences were not statistically significant $(p=0.2)$ (Figure $2 C)$. In addition, recipient to transmitter $\mathrm{T}-20 \mathrm{IC}_{50}$ ratio did not demonstrate a significant negative correlation with days from acquisition $(\rho=0.28, p=0.47)$ (Figure 2F).

\section{Replication in primary peripheral blood mononuclear cells}

Replication differences in early target cells potentially influences which virus establishes a new infection within a naïve host. We compared replication among viruses with recipient versus transmitter envelopes in activated CD4+ T cells from 4 different blood donation volunteers. There was large variation in AUC between the different blood donor's cells suggesting that different blood donation volunteers $\mathrm{CD} 4+\mathrm{T}$ cells supported replication to varying levels (Additional file 1: Figure S2). First, results from each blood donation volunteer's cells were analyzed independently. Recipient and transmitter envelope viruses displayed no statistically significant replication differences $(p>0.05)$ in any of the 4 blood donation volunteer's CD4+ T cells. Next, we conducted an aggregate examination of newly infected subject's virus AUC relative to the corresponding transmitting partner's virus AUC (Figure 3A). The median recipient to transmitter envelope virus AUC ratio in the CD4+ T cells from 4 different blood donation volunteers was 0.55 (range $0.01-5.21$ ). A value below 1 indicates that the transmitter envelope virus replicated to higher level compared to the corresponding recipient envelope variants. Although, in 5 of the 9 pairs, the recipient as compared to the transmitter virus replicated better in at least one blood donation volunteer's CD4+ T cells, in aggregate, transmitter envelope viruses were significantly better at replicating in activated $\mathrm{CD} 4+\mathrm{T}$ cells compared to recipient envelope viruses $(\mathrm{p}=0.03)$. The interval between sampling and estimated acquisition did not significantly correlate with recipient to transmitter AUC ratio $(\rho=0.32$, $\mathrm{p}=0.40$ ), suggesting that this difference was relatively stable (Figure 3B).

\section{Replication in dendritic cells with and without autologous T cells}

Intact mucosa prevents direct access to CD4+ T cells because these cells are mostly present in deeper submucosal locations [49-52]. Cells of the monocyte lineage, such as DCs, are thought to provide a conduit for the virus to sub-epithelial CD4+ T cells [53]. We compared replication among recipient and transmitter envelope viruses in MDDCs in the absence or presence of autologous activated CD4+ T cells. First, we independently examined replication in immature and mature MDDC exposed to infectious virus. None of the 18 different virus stocks replicated in immature and mature MDDCs
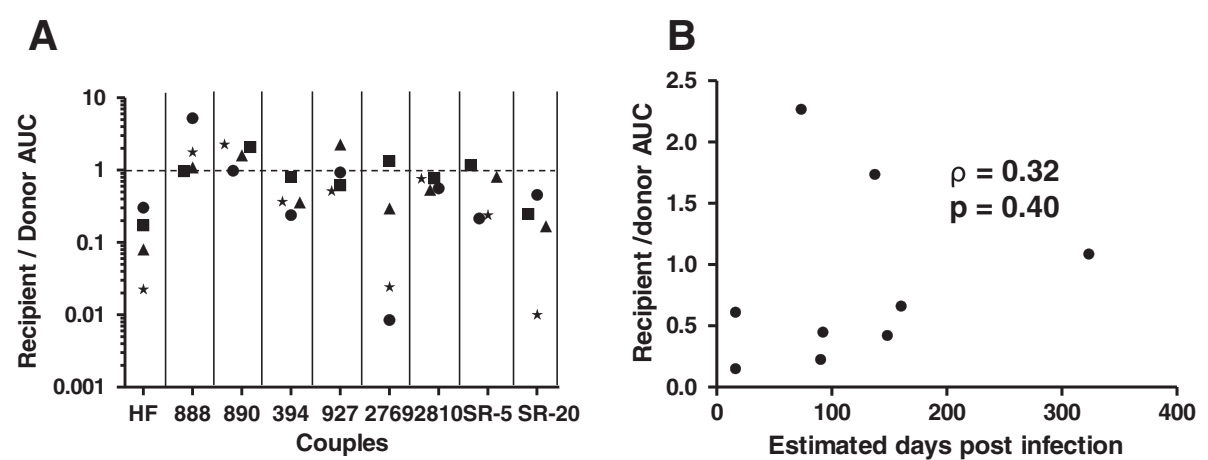

Figure 3 Transmitter envelope viruses replicate significantly better than recipient envelope viruses in CD4+ T cells. (A) Recipient relative to transmitter envelope virus replication area under the curve (AUC) among CD4+ T cells from blood donation volunteer 1 (circle), 2 (square), 3 (triangle), and 4 (star). X-axis shows the couple's ID. The dotted line at a ratio of 1 separates instances when the recipient envelope viruses replicated to a greater extent than the transmitter envelope viruses $(>1)$ or vice-versa $(<1)$. (B) Correlation between interval from estimated infection to sampling and recipient to transmitter CD4+ T cell replication AUC ratio. Graph also shows the correlation coefficient with a Spearman rank correlation $p$ - value. 
from 2 of the 3 blood donation volunteers. In one blood donation volunteer's immature and mature MDDCs, low level replication was observed among a small number of transmitter and recipient envelope viruses (Additional file 1: Figure S3). These results confirmed that both immature and mature DCs are rarely productively infected when exposed to low levels of infectious virus potentially because of low CD4 and CCR5 surface receptor levels and potent anti-viral responses [39,54].

Next, we examined replication in MDDC - autologous CD4+ $\mathrm{T}$ cell co-cultures. Replication levels varied between the different blood donation volunteer's immature and mature MDDCs - CD4+ T cell co-cultures (Additional file 1: Figure S4). Transmitter as compared to recipient envelope viruses replicated significantly more $(\mathrm{p}<0.05)$ in each of the 4 different blood donation volunteer's mature DC - autologous CD4+ T cell cocultures. In aggregate, the transmitter envelope viruses replicated to higher level compared to the corresponding recipient envelope variants (median 0.32, range 0.009 2.77, $\mathrm{p}<0.001$ ) (Figure 4A). On the other hand, recipient and transmitter envelope viruses displayed no statistically significant replication differences $(\mathrm{p}>0.05)$ in any of the 4 blood donor's immature DC - CD4+ T cells co-cultures.
In aggregate, transmitter envelope viruses were better at replicating in immature MDDC - CD4+ T cell cultures than recipient envelope variants (median recipient to transmitter AUC 0.71, range 0.003 - 253.9), although this was not statistically significant $(\mathrm{p}=0.30)$ (Figure $4 \mathrm{~B})$. The interval between sampling and estimated acquisition did not significantly correlate with recipient to transmitter AUC ratio for either mature $(\rho=0.08, p=0.85)$ (Figure 4C) or immature MDDC $(\rho=0.45, p=0.23)$ (Figure 4D).

\section{Replication in skin derived Langerhans cells heterologous $T$ cell co-cultures}

Genital mucosa contain specific tissue resident DCs, termed LCs [55,56]. Because LCs project dendrites over the lumen, they are likely the first DC subset that encounters incoming HIV-1. We compared replication differences among recipient versus transmitter envelope viruses in these cells $[49,50]$. LCs were isolated from anonymous discarded skin obtained from reduction mammoplasties using previously described methods $[57,58]$. More than $90 \%$ of the isolated cells expressed langerin and CD1a, a hallmark of LCs (Additional file 1: Figure S5). Similar to the MDDCs, virus failed to replicate in skin LC cultures alone but did propagate in
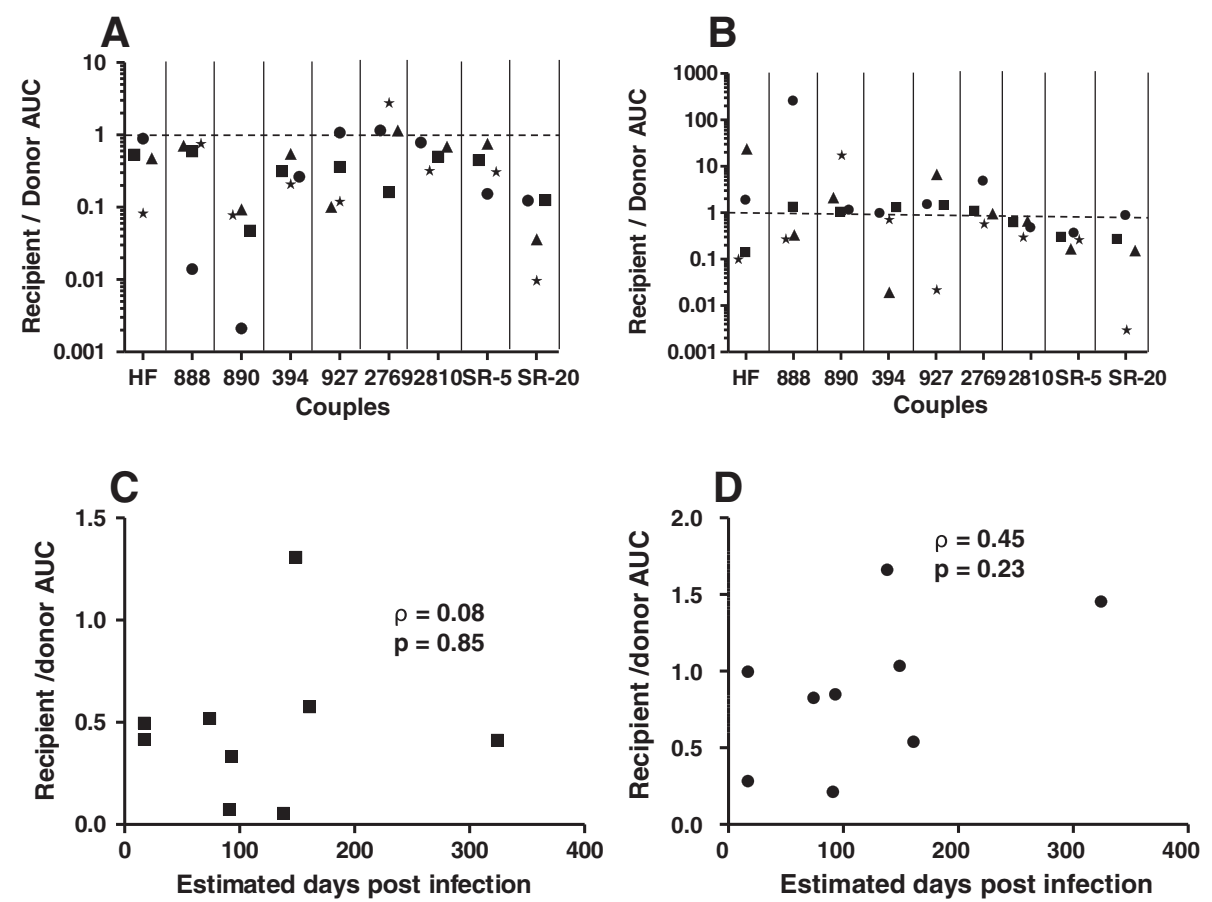

Figure 4 Transmitter envelope viruses have higher replication compared to recipient envelope viruses in monocyte derived dendritic cells (MDDC) - autologous CD4+ T cell cultures. Recipient relative to transmitter envelope virus replication AUC among mature MDDCs autologous CD4+ T cells (A) and immature MDDCs - autologous CD4+ T cells (B) from blood donation volunteer 1 (circle), 2 (square), 3 (triangle), and 4 (star) respectively. The $x$-axis shows the couple's ID. The dotted line at a ratio of 1 separates instances when the recipient envelope viruses replicated to a greater extent than the transmitter envelope viruses $(>1)$ or vice-versa $(<1)$. The bottom graphs show correlation between interval from estimated infection to sampling and recipient to transmitter replication AUC ratio in mature MDDC (C) and immature MDDC (D). Graphs also shows the correlation coefficient with the Spearman rank correlation $p$ - values. 
$\mathrm{LC}$ - activated $\mathrm{CD} 4+\mathrm{T}$ cell co-cultures. All viruses replicated in 1 donor's LCs - CD4+ T cell co-cultures, but replication was observed among some of the recipient and transmitter envelope viruses in the remaining co-cultures with LCs from 9 other skin tissue donors. In the 1 donor's LCs that supported replication of all variants, higher amounts of infectious virus was observed in transmitter as compared to recipient envelope viruses in 7 of the 9 couples, and this difference was marginally significant $(\mathrm{p}=0.05)$. In aggregate, the transmitter envelope viruses replicated to higher level compared to the corresponding recipient envelope variants (median recipient to transmitter AUC 0.75, range $0.07-3.83, \mathrm{p}=0.02$ ) among the cases where viruses from both partners in a relationship demonstrated replication (Figure 5A). In 19 instances virus from only 1 of the partners in a relationship (13 transmitter and 6 recipient) replicated in the $\mathrm{LC}-\mathrm{CD} 4+\mathrm{T}$ cell cocultures. The replication AUC ratio between recipient and transmitter envelope viruses increased with the interval of time between estimated infection and sampling $(\rho=0.78, p=0.02)$ (Figure $5 B)$. This suggests that the recipient envelope viruses most closely related to the potential infecting strains (i.e. those sampled earliest after estimated HIV-1 acquisition) demonstrated the least efficient replication in $\mathrm{LC}-$ heterologous CD4+ T cells cultures compared to the corresponding transmitting partner's envelope variants.

\section{Alpha4beta7 integrin usage}

It has been suggested that viruses with enhanced binding to the gut homing integrin, $\alpha 4 \beta 7$, are more likely to disseminate from the initial site of invasion to GALT, which is potentially important for establishing a systemic infection [32-34]. Previous studies from our group and others have shown that $\alpha 4 \beta 7$ inhibitors often fail to prevent virus binding to and replication in cells expressing high levels of $\alpha 4 \beta 7[26,59]$. Thus, retinoic acid (RA) stimulated CD8+ and CD4+ T cells with flow cytometry confirmed up-regulated $\alpha 4 \beta 7$ expression were used to compare integrin binding and replication among recipient and transmitter envelopes in the absence of inhibitors (Additional file 1: Figure S6) [32,33]. Amount of HIV-1 RNA bound to $\alpha 4 \beta 7$ high CD $8+$ T cells was used to estimate binding to the gut homing integrin. One of the 4 blood donor's cells demonstrated significantly greater transmitter as compared to recipient envelope virus binding to $\alpha 4 \beta 7 \mathrm{CD} 8+\mathrm{T}$ cells $(\mathrm{p}=0.03)$. In aggregate, transmitter relative to recipient envelope viruses demonstrated significantly higher binding to $\alpha 4 \beta 7$ high $\mathrm{CD} 8+\mathrm{T}$ cells (median recipient to transmitter ratio 0.74 , range $0.03-6.49, \mathrm{p}=0.04$ ) (Figure $6 \mathrm{~A}$ ). In addition, there was a positive trend between the recipient to transmitter $\alpha 4 \beta 7$ high CD8 $+\mathrm{T}$ cells binding ratio and days post infection $(p=0.60, p=0.10)$ (Figure $6 \mathrm{~B})$.

We further compared recipient versus transmitter envelope virus replication in RA exposed flow cytometry confirmed CD4+ $\mathrm{T}$ cells expressing high cell surface levels of the $\alpha 4 \beta 7$ receptor from 4 different blood donation volunteers. In 1 of the 4 blood donor's cells, higher replication was observed among the transmitter as compared to recipient envelope viruses $(p=0.01)$. In aggregate, transmitter as compared to recipient viruses showed significantly greater replication in $\alpha 4 \beta 7$ high CD4+ T cells (median recipient to transmitter ratio 0.51, range $0.10-6.89, \mathrm{p}=0.01$ ) (Figure $6 \mathrm{C}$ ). There was, however, a negative correlation $(\rho=-0.36, p=0.34)$ between time post infection and recipient to transmitter replication ratio in $\alpha 4 \beta 7$ high $\mathrm{CD} 4+\mathrm{T}$ cells, although it was not statistically significant (Figure 6D). The goodness of
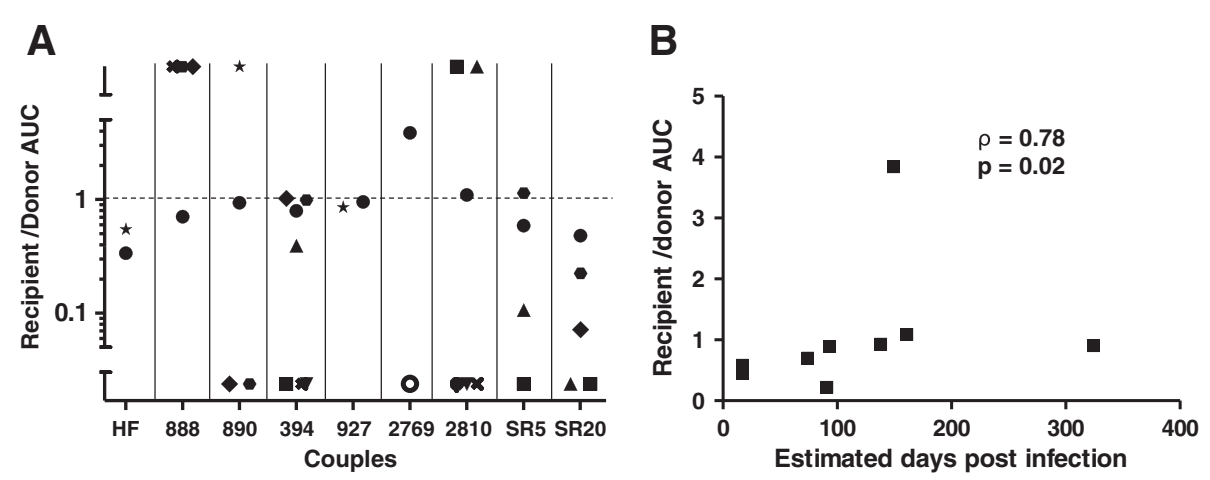

Figure 5 Transmitter as compared to recipient envelope viruses replicate to higher levels in Langerhans cells (LCS) - heterologous activated CD4+ T cell cultures. (A) Recipient relative to transmitter envelope virus replication AUC among the 10 different skin donation volunteers LCs. Each symbol represents LCs from a different subject. The $x$-axis shows the couple's ID. The dotted line at a ratio of 1 separates instances when the recipient envelope viruses replicated to a greater extent than the transmitter envelope viruses $(>1)$ or vice-versa $(<1)$. Symbols in the bottom and top third of the $y$-axis depict instances where replication was observed either only in the recipient or transmitter envelope virus within a partnership respectively. (B) Correlation between interval from estimated infection to sampling and recipient to transmitter replication AUC ratio. Graphs also shows the correlation coefficient with the Spearman rank correlation $p$ - values. 
A

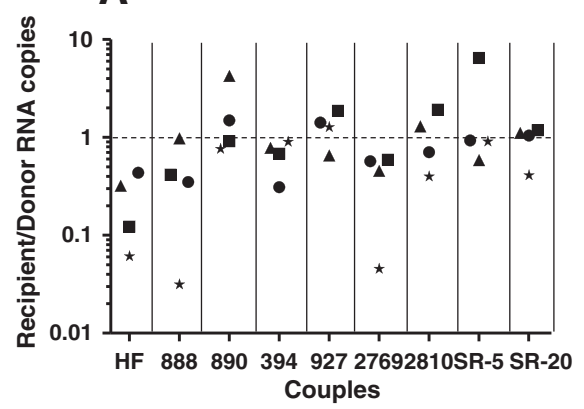

C

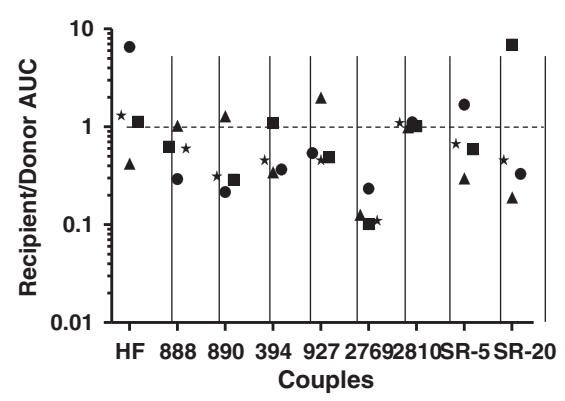

B

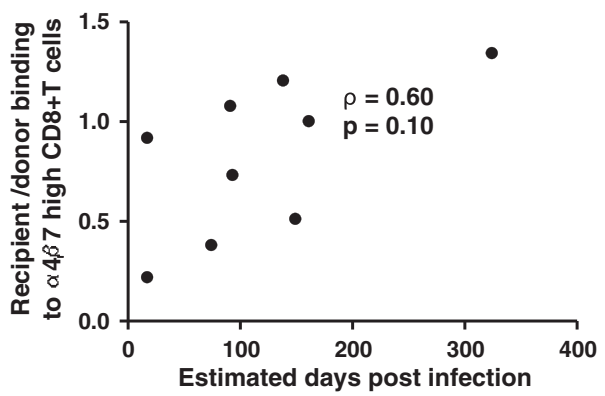

D

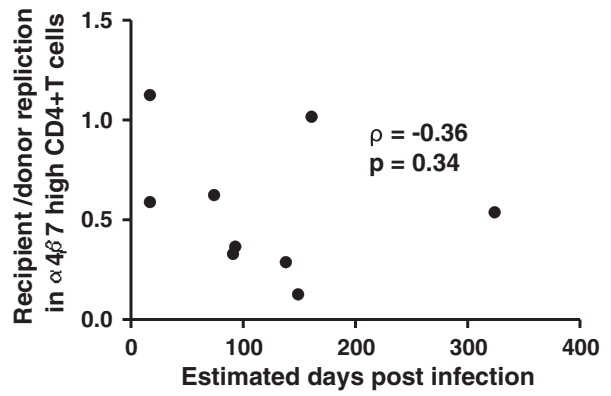

Figure 6 Transmitter envelope viruses demonstrate higher a4 37 usage. Graph A and C show recipient versus transmitter HIV-1 RNA copies recovered from a $4 \beta 7$ high / CD8+ T cells (A) and ratio of recipient to transmitter infectious virus concentration in the culture supernatant 3 days post-infection of a $4 \beta 7$ high / CD4+ T cells (C). The $x$-axis shows the couple's ID. The dotted line at a ratio of 1 separates instances when the recipient envelope viruses demonstrated greater binding or replication relative to the transmitter envelope viruses $(>1)$ or vice-versa $(<1)$. Graph $B$ and D show correlation between interval from estimated infection to sampling and recipient to transmitter a4 37 high CD8+ T cell binding ratio (B) and $a 4 \beta 7$ high CD4+ T cell replication ratio (D). Graphs also shows the correlation coefficient with the Spearman rank correlation $p$ - value.

the fit was not significantly better assuming either a polynomial or exponential decay (data not shown).

\section{Discussion}

The combined envelope analysis from couples examined in this study and a previous investigation confirm that there is a selection for envelopes with signature genotypes, such as smaller less charged envelopes that are more closely related to ancestral strains [12]. One possibility is that the infectious source, i.e. genital secretions, contains a limited number of HIV-1 variants that are enriched in the envelope genotypes commonly observed in newly infected subjects. Source fluid studies, however, have failed to confirm this hypothesis [60-70]. Excluding random chance and infectious source compartmentalization suggests that transmitted viruses possess unique envelope properties that provide an advantage during transmission. To assess this issue, we examined various envelope phenotypic properties. We showed that recipient in comparison to the transmitter envelopes demonstrated no significant difference in the ability to use lower levels of the CD4 or CCR5 receptor, and they also had similar fusion characteristics. Interestingly, our correlation with days post infection analysis showed that recipient viruses isolated close to transmission were more sensitive to
CCR5 inhibition compared to those sampled further from the estimated acquisition time. This buttresses previous conclusions that viruses found early compared to those circulating during the chronic phase of infection require relatively higher CCR5 levels for infection [24,36,42-46]. Transmitter envelope viruses were better at replicating in $\mathrm{CD} 4+\mathrm{T}$ cells and DC/LC - CD4+ T cell co-cultures compared to recipient envelope recombinants. Transmitter envelope viruses also demonstrated significantly greater replication and enhanced binding to $\mathrm{CD} 4+$ and $\mathrm{CD} 8+\mathrm{T}$ cells expressing high levels of the gut homing integrin. Collectively, viruses found early after infection have unique envelope genotypic characteristics, and variants with these genotypes do not have enhanced replication in potential early target cells or dissemination from the initial site of invasion using the gut homing integrin.

The SIV - macaque animal model shows that exposure to high levels of infectious virus leads to multiple small foci of localized infections at the site of invasion [29]. Other highly susceptible cells, such as CD4+ T cells, are recruited to these infectious clusters promoting infection dissemination and systemic spread. Similar to the SIV - macaque model, HIV-1 infection may begin with one or a small number of infected cells, and spread from these foci to other susceptible targets may disseminate the 
infection. We examined infection in LCs because LCs project their dendrites over lumen exposed epithelia, and thus they are likely the first DC subset that encounters incoming HIV-1 [49-52]. Prior studies have documented that R5 but not X4 viruses can infect LCs [18,71-74]. This counter-selection against X4 viruses has not been observed in any other mucosal cells, such as CD4+ $\mathrm{T}$ cells or MDDCs. This strongly suggests that LCs may function as the gatekeeper determining which viruses establish a productive infection. In our studies, however, we found that transmitter as compared to recipient envelope viruses replicated more efficiently in skin derived LCs - heterologous CD4+ $\mathrm{T}$ cell co-cultures. It should be noted, however, that we obtained LCs from discarded breast skin. Newer studies suggest that mucosal LCs are phenotypically different from skin LCs. Murine models demonstrate that genital LCs have different ontogeny and receptor expression compared to skin derived LCs $[75,76]$. Human ex vivo vaginal tissue studies also show that lumen exposed genital LCs may not express langerin, which is a hallmark of skin derived LCs [77]. One study suggests that langerin traffics low levels of incoming HIV-1 away from a productive infection pathway towards degradation [78]. Thus, genital as compared to skin LCs may be inherently more susceptible to HIV-1. Furthermore, it has been suggested that genital LCs capture infectious virus and disseminate them to other susceptible target cells without being productively infected [77]. On the other hand, HIV-1 productively infects skin derived LCs, and infection can be blocked by specific receptor inhibitors [71,78-80]. In aggregate, skin derived LCs are not ideal surrogates for genital LCs. Infection studies have not been conducted with genital LCs because it has been difficult to isolate adequate numbers with sufficient purity. Future studies will need to examine if genital LCs dictate the observed genetic restriction during transmission.

Besides LCs, mucosal tissues also contain CD4+ T cells and other DC subsets, such as DC-SIGN + DCs. These cells, however, have limited direct access to the lumen within intact mucosa $[49,50]$. It is possible that LCs counter-select against X4 HIV-1, and the deeper lying cells preferentially select specific R5 variants from the diverse CCR5 using viruses present in the infectious source. We, however, found that transmitter as compared to recipient envelope viruses were better at replicating in CD4+ $\mathrm{T}$ cells and monocyte derived $\mathrm{DC}-\mathrm{T}$ cell co-cultures, a surrogate for the DC-SIGN + DCs present in the mucosa. It has been demonstrated that DCs can capture virions and retain them in an infectious state for an extended period of time and then spread them to other permissive cells [80-85]. This trans infection pathway spreads HIV-1 more efficiently compared to cell-free virus infections. CD4+ T cells and DCs/LCs may still be some of the earliest cellular targets, but these cells likely do not dictate which variants circulating in the transmitting partner establishes a disseminated infection in the newly infected individual.

Disseminating from the initial infection focus could also influence which virus establishes a new infection in a naïve host. It has been speculated that attachment to the $\alpha 4 \beta 7$ integrin facilitates virus migration from mucosal sites to GALT, where high level replication occurs early after HIV-1 acquisition [31-33]. Indeed, some HIV1 envelope surface subunits, gp120s, with transmission/ early infection genotypes, such as shorter and less glycosylated variable loops, had higher binding to the $\alpha 4 \beta 7$ receptor compared to chronic phase gp120s [34,59]. We, however, found recipient as compared to transmitter envelope viruses demonstrated decreased attachment to CD8+ $\mathrm{T}$ cells and lower replication in CD4+ $\mathrm{T}$ cells expressing high levels of the $\alpha 4 \beta 7$ receptor, although this finding was not consistent among all the blood donor cells. This suggests that further studies on $\alpha 4 \beta 7$ utilization may be necessary to determine its exact role in transmission. In contrast to the previous study, we examined $\alpha 4 \beta 7$ interactions with envelope glycoproteins in the context of a virus particle and not with a gp120 envelope subunit [34]. Recent structural studies suggest that exposure of important envelope domains, such as the $\alpha 4 \beta 7$ binding site, potentially differs between a gp120 subunit compared to trimers on virus particles [86,87]. Although, our results suggest that enhanced $\alpha 4 \beta 7$ utilization may not provide a selective advantage during transmission, we did observe a nonsignificant negative correlation between replication in $\alpha 4 \beta 7$ high CD4+ T cells and days post-infection, suggesting that if this is a potential transmission phenotype it is lost relatively early after infection.

A recent study showed that full-length T/F as compared to chronic stage viruses have both enhanced cell free infectivity and MDDC usage potentially due to increased envelope expression [27]. In contrast to our investigation of subtype D HIV-1, they examined subtype $B$ and $C$ viruses. Because HIV-1 subtype D may have different phenotypic characteristics compared to the other clades, properties of the envelope variants found early after infection may be subtype dependent [88-91]. Most importantly, the T/F viruses were not compared to the variants circulating in the transmitting partner. Specific variants are acquired presumably because they possess a phenotypic property that confers fitness for transmission compared to the swarm circulating in the transmitting partner. This transmission phenotype may not necessarily distinguish all $\mathrm{T} / \mathrm{F}$ viruses from unrelated chronic phase variants. Viruses present in a transmitter likely possess different phenotypic properties compared to those isolated from unrelated subjects sampled during the chronic phase of disease. Thus, comparing full-length T/F 
to unrelated chronic stage variants is not ideal. Future studies that use full-length molecular clones from recipient transmitter pairs may be better able to identify a virus property that confers an advantage during mucosal HIV-1 transmission.

Unlike prior investigations that compared full-length envelopes from recipient transmitter pairs or phylogenetically estimated $\mathrm{T} / \mathrm{F}$ against unrelated chronic infection envelopes, we examined envelope properties in the context of a infectious clone as opposed to $293 \mathrm{~T}$ derived single cycle virus pseudotypes [21-23,26]. Single cycle infections limit the ability to interrogate small replication differences in relatively impermissible cells, such as LCs/DCs. Furthermore, PBMC generated virus has different number of envelope spikes with distinct types of glycans compared to the virions produced from $293 \mathrm{~T}$ transfections, which can influence receptor binding, neutralization and other properties [34,92,93]. Because glycan characteristics influence $\alpha 4 \beta 7$ binding and receptors present on LCs/DCs often interact with envelope carbohydrate moieties, PBMC generated viruses have more physiologically relevant phenotypes compared to the 293T transfection derived virions [34,94,95]. Although virus phenotypes can be altered among our PBMC passaged viruses, changes generally occur in long term cultures [96].

One of the primary limitations with our study is that we were not able to sample all the newly infected subjects at the earliest time after HIV-1 acquisition. Thus, we could not phylogenetically estimate the T/F sequence. Envelope gene modifications occur relatively early after HIV-1 acquisition [97,98]. These changes potentially affect envelope characteristics, and thus, viruses isolated early after acquisition may have different phenotypes compared to the transmitted strains. To partially address this concern, we examined correlations between the phenotype of interest and time post infection reasoning that a transient transmission property would demonstrate a significant negative correlation. Sensitivity to CD4 inhibitors and replication in $\alpha 4 \beta 7$ high $\mathrm{CD} 4+\mathrm{T}$ cells showed a negative correlation although they were not statistically significant. Because we were not able to evaluate the T/F variant, we used bulk PCR to better recapitulate the properties of the virus swarm at the time of sampling. Although, bulk PCR has been associated with polymerase induced recombination changes, this strategy allowed us to compare the envelopes from the newly infected subjects to the diverse variants circulating in the chronically infected transmitter and not just a small number of chronic infection strains [9]. We reasoned that if a transmission phenotype changed dramatically within the first year after acquisition, recipient and transmitter swarms should have similar characteristics. In contrast, we found that viruses found in recently infected subjects compared to those present in the transmitting partner had significantly lower infectivity and decreased binding. If enhanced replication capacity in primary cells and/or increased binding to the $\alpha 4 \beta 7$ integrin is the property that allows for the selection observed during transmission, then viruses with these potential transmission phenotypes must be selected against early after acquisition and subsequently enriched during the chronic phase of disease. Examination of longitudinally sampled viruses may help differentiate among these possibilities.

\section{Conclusion}

Counter-selection against X4 variants and preferential acquisition of R5 viruses with signature genotypes strongly suggests that the genetic restriction observed during mucosal HIV-1 acquisition is not a stochastic process. Mucosal LCs likely prevent CXCR4 using viruses from establishing a new infection. The biological mechanism, however, that favors specific R5 variants amongst the complex CCR5 using quasispecies circulating in the chronically infected transmitting partner still remains unclear. Our study of viruses incorporating recipient and transmitter envelopes suggests that replication capacity in potential early target cells and $\alpha 4 \beta 7$ integrin usage likely do not confer fitness for transmission. Comparing virus properties of full-length molecular clones from transmission pairs in the most relevant cells, such as mucosal LCs could shed valuable insights about the selective bottleneck during transmission. Vaccine and microbicide strategies that specifically target the virus characteristic that confers a fitness advantage during acquisition may be especially efficacious in preventing transmission.

\section{Methods}

\section{Subjects}

We examined newly infected monogamous subjects with their epidemiologically linked heterosexual partner from the RCCS in the Rakai district of southwestern Uganda $[99,100]$. In the RCCS, serum was collected approximately every 10 months for HIV-1 antibody testing, and newly seropositive subjects' previously seronegative sample was tested for HIV-1 RNA with a pooled viral load assay as previously described [101,102]. In seropositive incident subjects, the HIV-1 acquisition date was estimated as the midpoint between the last seronegative visit and the first HIV-1 antibody positive collection day. In seronegative individuals with HIV-1 RNA positive samples, acquisition was estimated as 17 days prior to sampling. This study was approved by human subjects review boards at the Uganda Virus Research Institute, the AIDS Research Subcommittee of the Ugandan National Council for Science and Technology, Johns 
Hopkins University, Brigham and Women's Hospital, and Boston University Medical Center. All subjects provided written informed consent.

\section{Envelope amplification and analysis}

HIV-1 RNA was isolated from around $100 \mathrm{ul}$ of the serum samples, and RT-PCR was used to amplify a library of fulllength envelope genes using previously described primers and amplification conditions [9]. For each subject, a minimum of four independent PCRs were pooled to generate a library of envelope genes from each serum sample. Pooled envelope amplifications were inserted into linearized $\mathrm{pCMV-NL4-3-PBS} \rightarrow$ LTR $\Delta$ Gp160 plasmid using yeast gap-repair homologous recombination as previously described [36,103]. All recombinant NL4-3 clones containing a subject's envelope genes were pooled to generate plasmids containing a library of the subjects' envelopes (pCMV-NL4-3-PBS $\rightarrow$ LTR + Envs). Eight to 12 individual full-length envelopes were isolated and sequenced from each subject's clones. The NL4-3 recombinants contained chimeric $\mathrm{Vpu}$, Tat, and Rev genes because the full-length envelope overlaps with these accessory virus proteins [104]. All unique sequences reported in this publication have been submitted to Genbank (KF985982 - KF986146). Transmission among individuals within a partnership was confirmed by the observed clustering in ML phylogenetic analysis. For each couple, ML phylogenies were generated using Paup with parameters from FindModel best fit evolutionary model as described previously [12]. The ML trees were used to estimate a MRCA and the distance from each sequence to the MRCA. Average of pairwise distances was used to estimate genetic diversity. Recipient and transmitter sequence divergence was estimated as the average distance from the recipient or transmitter estimated ancestor respectively as described previously [12]. Different envelope segments amino acid lengths and PNGS were analyzed as previously described [12].

\section{Replication competent recombinant viruses}

Viruses were generated by co-transfecting 293T cells with equivalent quantities of CMV-NL4-3-LTR $\rightarrow$ Gag4 and the library of recombinant NL4-3 with subject's envelopes (pCMV-NL4-3-PBS $\rightarrow$ LTR + Envs) as previously described [36]. Supernatants were collected 48 to 72 hours after transfection. Supernatants from 293T cells were passaged for a maximum of 7 days in activated PBMCs to generate higher titer virus stocks. The number of infectious particles was estimated on TZM-bl cells as previously described [25,105].

\section{Inhibitor sensitivity}

TZM-bl, U87/CD4/CXCR4 and U87/CD4/CCR5 cells, T-20, Maraviroc, and CD4 B4 monoclonal antibody were obtained through Research and Reference Reagent Program, Division of AIDS, NIAID, NIH [41,106,107]. Infection of TZM-bl cells in the absence and presence of two-fold serial dilution of the inhibitor was used to estimate the $50 \%$ inhibitory concentration $\left(\mathrm{IC}_{50}\right)$ as previously described [24]. All reported $\mathrm{IC}_{50} \mathrm{~S}$ are mean estimates from a minimum of 3 independent assays. Coreceptor usage was determined by monitoring p24 production in U87/CD4/CXCR4 and U87/CD4/CCR5 cells infected with 500 IP of each virus supernatant.

\section{Primary cells and infections}

Peripheral blood mononuclear cells were isolated from HIV-1 negative blood donation volunteer's buffy coats using Ficoll Hypaque density centrifugation. Monocytes were isolated from PBMCs using the percoll gradient method [108]. Primary human immature DCs were derived from monocytes, as described previously [109]. Briefly, monocytes were cultured in RPMI/10\% FBS containing recombinant human GM-CSF $(0.5 \mu \mathrm{g} / \mathrm{ml}$; Leukine, Berlex) and recombinant human IL-4, $100 \mathrm{U} / \mathrm{ml}$ (BD Biosciences) for 6 days. Mature DCs were obtained by culturing immature DCs at day six of culture for two additional days in the presence of $100 \mathrm{ng} / \mathrm{ml}$ of ultra-pure E. coli LPS (Sigma). Primary human CD4+ and CD8+ T cells were isolated from monocyte depleted PBMCs using antibody conjugated magnetic beads (Miltenyi Biotech) according to manufacturer's instructions. CD4+ T cells were activated with $2 \%$ phytohaemagglutinin (PHA) and $20 \mathrm{ug} / \mathrm{ml}$ recombinant human IL-2 (r-IL-2) for 2 days. LCs were obtained using previously described methods [57]. Briefly, normal human skin from reduction mammoplasties was acquired as discarded surgical tissue. The epidermis was mechanically separated from adipose tissue, and overnight dispase incubation was used to remove the dermis. Further trypsin digestion was used to extract individual cells. Immature LCs were obtained from the trypsinized epidermal cells by fractionating through a discontinuous OptiPrep density gradient. Langerhans cells were further purified from the epidermal cells using a magnetic CD1a microbead kit (Miltenyi Biotech) [57,58].

Around $2 \times 10^{6} \mathrm{CD} 4+\mathrm{T}$ cells were exposed to 1,000 infectious particles in the presence of $20 \mathrm{ug} / \mathrm{ml}$ diethylaminoethyl(DEAE)-Dextran. After two hours, cultures were washed a minimum of three times. Around $0.5 \times 10^{6}$ immature or mature DCs were independently exposed to 1,000 infectious particles. After three hours, DC cultures were washed a minimum of three times to remove unbound virus. Virus exposed DC infections were cultured either with or without autologous activated CD4+ T cells. Around $1 \times 10^{4}$ skin LCs and were exposed to 5,000 to 25,000 infectious virus. Cultures were washed after 72 hours to remove unbound virus, and then co-cultured with heterologous activated CD4+ T 
cells. Around $50 \%$ of the culture supernatant was removed every 3 to 4 days and replaced with fresh media. Culture supernatants were assessed for p24 antigen content using an in house assay as previously described [110]. Infectious virus concentration was also estimated by infecting $1 \times 10^{4}$ TZM-bl cells with 8 serial two-fold dilutions of supernatant culture starting at $50 \mathrm{ul}$. All infections were done in triplicate in a 96 well format. Two days post-infection, TZM-bls were examined for beta-galactosidase production using Galacto-Light Plus System (Applied Biosystems). A linear interpolated curve of the relative light units (RLUs) versus supernatant dilution was used to estimate RLU/ul. The AUC was generated from the RLU/ul from various days post infection. Primary cell infections were repeated a minimum of 4 times with cells from 4 different buffy coats or discarded surgical tissue.

\section{Replication in CD4+ and binding to CD8+ T cells expressing high a4 $\beta 7$ integrin levels}

Both CD8+ and CD4+ $\mathrm{T}$ cells were activated with PHA, r-IL-2, and RA for 6 days. Around $1 \times 10^{6}$ $\mathrm{CD} 8+$ and $\mathrm{CD} 4+\mathrm{T}$ cells were exposed to $1 \times 10^{5}$ infectious virus for 1 hour at $4^{\circ} \mathrm{C}$ in binding buffer (10 mM HEPES, $150 \mathrm{mM} \mathrm{NaCl}$ (HBS Buffer) buffer with $100 \mu \mathrm{M} \mathrm{CaCl} 2$ and $1 \mathrm{mM} \mathrm{MnCl2}$ ). Cells were washed a minimum of 3 times to remove unbound virus. RNA was isolated from the CD8+ $\mathrm{T}$ cells using the QIAAMP Viral RNA kit (QIAGEN). HIV-1 copies were quantified using quantitative RT-PCR using previously described methods [111,112]. The CD4+ T cells were incubated at $37^{\circ} \mathrm{C} 5 \% \mathrm{CO}_{2}$, and the infectious virus concentration in the culture supernatants was measured after 3 days as detailed above.

\section{Statistical analysis}

Summary characteristics of recipient virus envelopes were compared to the transmitter envelope variants using the Wilcoxon rank-sum test. Aggregate comparisons of the multiple recipient and transmitter envelopes among the different couples were done using the Wilcoxon rank-sum test stratified by pair. Recipient to transmitter ratios were compared to the expected value of 1 using the one-sample Wilcoxon signed-rank test. Recipient to transmitter ratio comparisons were stratified by different volunteers cells during the aggregate assessments. Correlations were assessed using the non-parametric Spearman rank correlation. All p-values were based on a two-sided test. All statistical analyses were done with either Intercooled Stata version 8.0 (Stata Corporation, College Station, TX) or SAS version 8.2 (SAS Institute, Cary NC).

\section{Additional file}

Additional file 1: Figure S1. Compares genetic diversity among virus stocks and bacterial clones. Figure S2-S4. Show replication characteristics in primary cells. Figure S5-S6. Show phenotypic characteristics of Langerhans cells and alpha4 beta7 expression in primary $T$ cells.

\section{Competing interests}

The authors declare that they have no competing interests.

\section{Authors' contributions}

VPC and BE constructed the viruses, conducted the replication and binding experiments and contributed to manuscript development. NC and PHN isolated the envelopes and performed the sequence analysis. SS and SJL did the statistical analysis. SJR, OL and DS were clinical site investigators. RHG and TQ contributed to data interpretation and manuscript development. MS designed the study, oversaw clinical and laboratory aspects of the study, analyzed and interpreted the data, and contributed to the manuscript development. All authors read and approved the final manuscript.

\section{Acknowledgements}

We thank all the subjects who have contributed samples for these studies as part of the Rakai Health Sciences Program. We thank Drs. Andrew Redd, James Arthos, and Suryaram Gummuluru for insightful comments on the manuscript. This study was supported by NIH grants Al077473 (MS) and by the Division of Intramural Research, NIAID, NIH. The funders had no role in study design, data collection and analysis, decision to publish, or preparation of the manuscript.

\section{Author details}

${ }^{1}$ Department of Medicine, Division of Infectious Diseases, Boston University, Boston, MA, USA. ${ }^{2}$ Department of Mathematics and Computer Science, College of the Holy Cross, Worcester, MA, USA. ${ }^{3}$ Department of Medicine, Johns Hopkins University School of Medicine, Baltimore, MD, USA. ${ }^{4}$ Division of Intramural Research, National Institute of Allergy and Infectious Diseases, National Institutes of Health, Bethesda, MD, USA. ${ }^{5}$ Department of Epidemiology, Bloomberg School of Public Health, Johns Hopkins University, Baltimore, MD, USA. ${ }^{6}$ Makerere University School of Public Health, Kampala, Uganda. ${ }^{7}$ Departments of Biostatistics and Computational Biology, Dana Farber Cancer Center, Boston, MA, USA. ${ }^{8}$ Boston University, Evans Biomedical Research Building, 650 Albany Street, Room 647, Boston, MA 02118-2518, USA.

Received: 10 October 2013 Accepted: 10 December 2013 Published: 26 December 2013

\section{References}

1. Zhu T, Mo H, Wang N, Nam DS, Cao Y, Koup RA, Ho DD: Genotypic and phenotypic characterization of HIV-1 patients with primary infection. Science 1993, 261:1179-1181.

2. Wolinsky SM, Wike CM, Korber BT, Hutto C, Parks WP, Rosenblum LL, Kunstman KJ, Furtado MR, Munoz JL: Selective transmission of human immunodeficiency virus type-1 variants from mothers to infants. Science 1992, 255:1134-1137.

3. Wolfs TF, Zwart G, Bakker M, Goudsmit J: HIV-1 genomic RNA diversification following sexual and parenteral virus transmission. Virology 1992, 189:103-110.

4. Long EM, Martin HL Jr, Kreiss JK, Rainwater SM, Lavreys L, Jackson DJ, Rakwar J, Mandaliya K, Overbaugh J: Gender differences in HIV-1 diversity at time of infection. Nat Med 2000, 6:71-75.

5. Sagar M, Kirkegaard E, Long EM, Celum C, Buchbinder S, Daar ES, Overbaugh J: Human immunodeficiency virus type 1 (HIV-1) diversity at time of infection is not restricted to certain risk groups or specific HIV-1 subtypes. J Virol 2004, 78:7279-7283.

6. Sagar M, Lavreys L, Baeten JM, Richardson BA, Mandaliya K, Ndinya-Achola JO, Kreiss JK, Overbaugh J: Identification of modifiable factors that affect the genetic diversity of the transmitted HIV-1 population. AIDS 2004, 18:615-619.

7. Haaland RE, Hawkins PA, Salazar-Gonzalez J, Johnson A, Tichacek A, Karita E, Manigart O, Mulenga J, Keele BF, Shaw GM, et al: Inflammatory genital 
infections mitigate a severe genetic bottleneck in heterosexual transmission of subtype A and C HIV-1. PLoS Pathog 2009, 5:e1000274.

8. Salazar-Gonzalez JF, Bailes E, Pham KT, Salazar MG, Guffey MB, Keele BF, Derdeyn CA, Farmer P, Hunter E, Allen S, et al: Deciphering human immunodeficiency virus type 1 transmission and early envelope diversification by single-genome amplification and sequencing. J Virol 2008, 82:3952-3970.

9. Keele BF, Giorgi EE, Salazar-Gonzalez JF, Decker JM, Pham KT, Salazar MG, Sun C, Grayson T, Wang S, Li H, et al: Identification and characterization of transmitted and early founder virus envelopes in primary HIV-1 infection. Proc Natl Acad Sci USA 2008, 105:7552-7557.

10. Gnanakaran S, Bhattacharya T, Daniels M, Keele BF, Hraber PT, Lapedes AS, Shen T, Gaschen B, Krishnamoorthy M, Li H, et al: Recurrent signature patterns in HIV-1 B clade envelope glycoproteins associated with either early or chronic infections. PLoS Pathog 2011, 7:e1002209.

11. Derdeyn CA, Decker JM, Bibollet-Ruche F, Mokili JL, Muldoon M, Denham SA, Heil ML, Kasolo F, Musonda R, Hahn BH, et al: Envelope-constrained neutralization-sensitive HIV-1 after heterosexual transmission. Science 2004, 303:2019-2022.

12. Sagar M, Laeyendecker O, Lee S, Gamiel J, Wawer MJ, Gray RH, Serwadda D, Sewankambo NK, Shepherd JC, Toma J, et al: Selection of HIV variants with signature genotypic characteristics during heterosexual transmission. J Infect Dis 2009, 199:580-589.

13. Chohan B, Lang D, Sagar M, Korber B, Lavreys L, Richardson B, Overbaugh J: Selection for human immunodeficiency virus type 1 envelope glycosylation variants with shorter V1-V2 loop sequences occurs during transmission of certain genetic subtypes and may impact viral RNA levels. J Virol 2005, 79:6528-6531.

14. Frost SD, Liu Y, Pond SL, Chappey C, Wrin T, Petropoulos CJ, Little SJ, Richman DD: Characterization of human immunodeficiency virus type 1 (HIV-1) envelope variation and neutralizing antibody responses during transmission of HIV-1 subtype B. J Virol 2005, 79:6523-6527.

15. Sagar M: HIV-1 transmission biology: selection and characteristics of infecting viruses. J Infect Dis 2010, 202(Suppl 2):S289-S296.

16. Brumme ZL, Goodrich J, Mayer HB, Brumme CJ, Henrick BM, Wynhoven B, Asselin JJ, Cheung PK, Hogg RS, Montaner JS, Harrigan PR: Molecular and clinical epidemiology of CXCR4-using HIV-1 in a large population of antiretroviral-naive individuals. J Infect Dis 2005, 192:466-474.

17. Scarlatti G, Tresoldi E, Bjorndal A, Fredriksson R, Colognesi C, Deng HK, Malnati MS, Plebani A, Siccardi AG, Littman DR, et al: In vivo evolution of HIV-1 co-receptor usage and sensitivity to chemokine-mediated suppression. Nat Med 1997, 3:1259-1265.

18. Zaitseva M, Blauvelt A, Lee S, Lapham CK, Klaus-Kovtun V, Mostowski H, Manischewitz J, Golding H: Expression and function of CCR5 and CXCR4 on human Langerhans cells and macrophages: implications for HIV primary infection. Nat Med 1997, 3:1369-1375.

19. Redd AD, Collinson-Streng AN, Chatziandreou N, Mullis CE, Laeyendecker O, Martens C, Ricklefs S, Kiwanuka N, Nyein PH, Lutalo T, et al: Previously transmitted HIV-1 strains are preferentially selected during subsequent sexual transmissions. J Infect Dis 2012, 206:1433-1442.

20. Herbeck JT, Nickle DC, Learn GH, Gottlieb GS, Curlin ME, Heath L, Mullins J: Human immunodeficiency virus type 1 env evolves toward ancestral states upon transmission to a new host. J Virol 2006, 80:1637-1644.

21. Wilen $C B$, Parrish NF, Pfaff JM, Decker JM, Henning EA, Haim H, Petersen JE, Wojcechowskyj JA, Sodroski J, Haynes BF, et al: Phenotypic and immunologic comparison of clade B transmitted/founder and chronic HIV-1 envelope glycoproteins. J Virol 2011, 85:8514-8527.

22. Alexander M, Lynch R, Mulenga J, Allen S, Derdeyn CA, Hunter E: Donor and recipient envs from heterosexual human immunodeficiency virus subtype $\mathrm{C}$ transmission pairs require high receptor levels for entry. J Virol 2010, 84:4100-4104.

23. Isaacman-Beck J, Hermann EA, Yi Y, Ratcliffe SJ, Mulenga J, Allen S, Hunter E, Derdeyn CA, Collman RG: Heterosexual transmission of human immunodeficiency virus type 1 subtype C: Macrophage tropism, alternative coreceptor use, and the molecular anatomy of CCR5 utilization. J Virol 2009, 83:8208-8220.

24. Etemad B, Fellows A, Kwambana B, Kamat A, Feng Y, Lee S, Sagar M: Human immunodeficiency virus type 1 V1-to-V5 envelope variants from the chronic phase of infection use CCR5 and fuse more efficiently than those from early after infection. J Virol 2009, 83:9694-9708.
25. Sagar M, Wu X, Lee S, Overbaugh J: HIV-1 V1-V2 envelope loop sequences expand and add glycosylation sites over the course of infection and these modifications affect antibody neutralization sensitivity. J Virol 2006, 80:9586-9598.

26. Parrish N, Wilen C, Banks L, lyer S, Pfaff J, Salazar-Gonzalez J, Salazar MG, Decker JM, Parrish E, Berg A, et al: Transmitted/founder and chronic subtype C HIV-1 use CD4 and CCR5 receptors with equal efficiency and are not inhibited by blocking the integrin a4b7. PLoS Pathog 2012, 8:e1002686.

27. Parrish NF, Gao F, Li H, Giorgi EE, Barbian HJ, Parrish EH, Zajic L, lyer SS, Decker JM, Kumar A, et al: Phenotypic properties of transmitted founder HIV-1. Proc Natl Acad Sci U S A 2013, 110:6626-6633.

28. Li Q, Duan L, Estes JD, Ma ZM, Rourke T, Wang Y, Reilly C, Carlis J, Miller CJ, Haase AT: Peak SIV replication in resting memory CD4+ T cells depletes gut lamina propria CD4+ T cells. Nature 2005, 434:1148-1152.

29. Li Q, Estes JD, Schlievert PM, Duan L, Brosnahan AJ, Southern PJ, Reilly CS, Peterson ML, Schultz-Darken N, Brunner KG, et al: Glycerol monolaurate prevents mucosal SIV transmission. Nature 2009, 458:1034-1038.

30. Cohen MS, Gay CL, Busch MP, Hecht FM: The detection of acute HIV infection. J Infect Dis 2010, 202(Suppl 2):S270-S277.

31. Mehandru S, Poles MA, Tenner-Racz K, Horowitz A, Hurley A, Hogan C, Boden D, Racz P, Markowitz M: Primary HIV-1 infection is associated with preferential depletion of $\mathrm{CD} 4+\mathrm{T}$ lymphocytes from effector sites in the gastrointestinal tract. J Exp Med 2004, 200:761-770.

32. Arthos J, Cicala C, Martinelli E, Macleod K, Van Ryk D, Wei D, Xiao Z, Veenstra TD, Conrad TP, Lempicki RA, et al: HIV-1 envelope protein binds to and signals through integrin alpha4beta7, the gut mucosal homing receptor for peripheral T cells. Nat Immunol 2008, 9:301-309.

33. Cicala C, Martinelli E, McNally JP, Goode DJ, Gopaul R, Hiatt J, Jelicic K, Kottilil S, Macleod K, O'Shea A, et al: The integrin alpha4beta7 forms a complex with cell-surface CD4 and defines a T-cell subset that is highly susceptible to infection by HIV-1. Proc Natl Acad Sci USA 2009, 106:20877-20882.

34. Nawaz F, Cicala C, Van Ryk D, Block KE, Jelicic K, McNally JP, Ogundare $O$, Pascuccio M, Patel N, Wei D, et al: The genotype of early-transmitting HIV gp120s promotes alpha (4) beta (7)-reactivity, revealing alpha (4) beta (7) $+/$ CD4+ T cells as key targets in mucosal transmission. PLoS Pathog 2011, 7:e1001301.

35. Liu SL, Rodrigo AG, Shankarappa R, Learn GH, Hsu L, Davidov O, Zhao LP, Mullins JI: HIV quasispecies and resampling. Science 1996, 273:415-416.

36. Chatziandreou N, Arauz AB, Freitas I, Nyein PH, Fenton G, Mehta SH, Kirk GD, Sagar M: Sensitivity changes over the course of infection increases the likelihood of resistance against fusion but not CCR5 receptor blockers. AIDS Res Hum Retroviruses 2012, 28:1584-1593.

37. De Jong JJ, De Ronde A, Keulen W, Tersmette M, Goudsmit J: Minimal requirements for the human immunodeficiency virus type 1 V3 domain to support the syncytium-inducing phenotype: analysis by single amino acid substitution. J Virol 1992, 66:6777-6780.

38. Fouchier RA, Groenink M, Kootstra NA, Tersmette M, Huisman HG, Miedema F, Schuitemaker H: Phenotype-associated sequence variation in the third variable domain of the human immunodeficiency virus type $1 \mathrm{gp} 120$ molecule. J Virol 1992, 66:3183-3187.

39. Lee B, Sharron M, Montaner $\sqcup$, Weissman D, Doms RW: Quantification of CD4, CCR5, and CXCR4 levels on lymphocyte subsets, dendritic cells, and differentially conditioned monocyte-derived macrophages. Proc Natl Acad Sci U S A 1999, 96:5215-5220.

40. Lobritz MA, Marozsan AJ, Troyer RM, Arts EJ: Natural variation in the V3 crown of human immunodeficiency virus type 1 affects replicative fitness and entry inhibitor sensitivity. J Virol 2007, 81:8258-8269.

41. Wang CY, Sawyer LS, Murthy KK, Fang X, Walfield AM, Ye J, Wang JJ, Chen PD, Li ML, Salas MT, et al: Postexposure immunoprophylaxis of primary isolates by an antibody to HIV receptor complex. Proc Natl Acad Sci USA 1999, 96:10367-10372.

42. Jansson M, Popovic M, Karlsson A, Cocchi F, Rossi P, Albert J, Wigzell H: Sensitivity to inhibition by beta-chemokines correlates with biological phenotypes of primary HIV-1 isolates. Proc Natl Acad Sci USA 1996, 93:15382-15387.

43. Koning FA, Kwa D, Boeser-Nunnink B, Dekker J, Vingerhoed J, Hiemstra H, Schuitemaker H: Decreasing sensitivity to RANTES (regulated on activation, normally $\mathrm{T}$ cell-expressed and -secreted) neutralization of $\mathrm{CC}$ chemokine receptor 5-using, non-syncytium-inducing virus variants in 
the course of human immunodeficiency virus type 1 infection. $J$ Infect Dis 2003, 188:864-872

44. Repits J, Oberg M, Esbjornsson J, Medstrand P, Karlsson A, Albert J, Fenyo EM, Jansson M: Selection of human immunodeficiency virus type 1 R5 variants with augmented replicative capacity and reduced sensitivity to entry inhibitors during severe immunodeficiency. J Gen Virol 2005, 86:2859-2869

45. Redd AD, Laeyendecker O, Kong X, Kiwanuka N, Lutalo T, Huang W, Gray RH, Wawer MJ, Serwadda D, Eshleman SH, Quinn TC: Efficiency of CCR5 coreceptor utilization by the HIV quasispecies increases over time, but is not associated with disease progression. AIDS Res Hum Retroviruses 2011, 28:289-294.

46. Parker ZF, lyer SS, Wilen CB, Parrish NF, Chikere KC, Lee FH, Didigu CA, Berro R, Klasse PJ, Lee B, et al: Transmitted/Founder and Chronic HIV-1 Envelope Proteins Are Distinguished by Differential Utilization of CCR5. J Virol 2013, 87:2401-2411.

47. Reeves JD, Gallo SA, Ahmad N, Miamidian JL, Harvey PE, Sharron M, Pohlmann S, Sfakianos JN, Derdeyn CA, Blumenthal R, et al: Sensitivity of HIV-1 to entry inhibitors correlates with envelope/coreceptor affinity, receptor density, and fusion kinetics. Proc Natl Acad Sci USA 2002, 99:16249-16254.

48. Derdeyn CA, Decker JM, Sfakianos JN, Wu X, O'Brien WA, Ratner L, Kappes JC, Shaw GM, Hunter E: Sensitivity of human immunodeficiency virus type 1 to the fusion inhibitor T-20 is modulated by coreceptor specificity defined by the V3 loop of gp120. J Virol 2000, 74:8358-8367.

49. Patterson BK, Landay A, Andersson J, Brown C, Behbahani H, Jiyamapa D, Burki Z, Stanislawski D, Czerniewski MA, Garcia P: Repertoire of chemokine receptor expression in the female genital tract: implications for human immunodeficiency virus transmission. Am J Pathol 1998, 153:481-490.

50. Patterson BK, Landay A, Siegel JN, Flener Z, Pessis D, Chaviano A, Bailey RC Susceptibility to human immunodeficiency virus-1 infection of human foreskin and cervical tissue grown in explant culture. Am J Pathol 2002, 161:867-873.

51. Hirbod T, Kaldensjo T, Broliden K: In situ distribution of HIV-binding CCR5 and C-type lectin receptors in the human endocervical mucosa. PLOS One 2011, 6:e25551.

52. Hirbod T, Kaldensjo T, Lopalco L, Klareskog E, Andersson S, Uberti-Foppa C Ferrari D, Manghi M, Andersson J, Lore K, Broliden K: Abundant and superficial expression of $C$-type lectin receptors in ectocervix of women at risk of HIV infection. J Acquir Immune Defic Syndr 2009, 51:239-247.

53. Steinman RM, Granelli-Piperno A, Pope M, Trumpfheller C, Ignatius R, Arrode $G$, Racz P, Tenner-Racz K: The interaction of immunodeficiency viruses with dendritic cells. Curr Top Microbiol Immunol 2003, 276:1-30

54. Granelli-Piperno A, Chen D, Moser B, Steinman RM: The HIV-1 life cycle is blocked at two different points in mature dendritic cells. Adv Exp Med Biol 1997, 417:415-419.

55. Merad M, Ginhoux F, Collin M: Origin, homeostasis and function of Langerhans cells and other langerin-expressing dendritic cells. Nat Rev Immunol 2008, 8:935-947.

56. Romani N, Clausen BE, Stoitzner P: Langerhans cells and more: langerin-expressing dendritic cell subsets in the skin. Immunol Rev 2010 234:120-141.

57. Pena-Cruz V, Ito S, Oukka M, Yoneda K, Dascher CC, Von Lichtenberg F, Sugita M: Extraction of human Langerhans cells: a method for isolation of epidermis-resident dendritic cells. J Immunol Methods 2001, 255:83-91.

58. Pena-Cruz V, McDonough SM, Diaz-Griffero F, Crum CP, Carrasco RD, Freeman GJ: PD-1 on immature and PD-1 ligands on migratory human Langerhans cells regulate antigen-presenting cell activity. J Invest Dermatol 2010, 130:2222-2230.

59. Etemad B, Gonzalez OA, McDonough S, Pena-Cruz V, Sagar M: Early Infection HIV-1 Envelope V1-V2 Genotypes Do Not Enhance Binding or Replication in Cells Expressing High Levels of alpha4beta7 Integrin. J Acquir Immune Defic Syndr 2013, 63:249-253.

60. Boeras DI, Hraber PT, Hurlston M, Evans-Strickfaden T, Bhattacharya T, Giorgi EE, Mulenga J, Karita E, Korber BT, Allen S, et al: Role of donor genital tract HIV-1 diversity in the transmission bottleneck. Proc Natl Acad Sci USA 2011, 108:E1156-E1163.

61. Delwart EL, Mullins JI, Gupta P, Learn GH Jr, Holodniy M, Katzenstein D, Walker BD, Singh MK: Human immunodeficiency virus type 1 populations in blood and semen. J Virol 1998, 72:617-623.
62. Gupta P, Leroux C, Patterson BK, Kingsley L, Rinaldo C, Ding M, Chen $Y$, Kulka K, Buchanan W, McKeon B, Montelaro R: Human immunodeficiency virus type 1 shedding pattern in semen correlates with the compartmentalization of viral Quasi species between blood and semen. $J$ Infect Dis 2000, 182:79-87.

63. Kemal KS, Foley B, Burger H, Anastos K, Minkoff H, Kitchen C, Philpott SM, Gao W, Robison E, Holman S, et al: HIV-1 in genital tract and plasma of women: compartmentalization of viral sequences, coreceptor usage, and glycosylation. Proc Natl Acad Sci USA 2003, 100:12972-12977.

64. Paranjpe S, Craigo J, Patterson B, Ding M, Barroso P, Harrison L, Montelaro R, Gupta P: Subcompartmentalization of HIV-1 quasispecies between seminal cells and seminal plasma indicates their origin in distinct genital tissues. AIDS Res Hum Retroviruses 2002, 18:1271-1280.

65. Wong JK, Ignacio CC, Torriani F, Havlir D, Fitch NJ, Richman DD: In vivo compartmentalization of human immunodeficiency virus: evidence from the examination of pol sequences from autopsy tissues. J Virol 1997, 71:2059-2071

66. Andreoletti L, Skrabal K, Perrin V, Chomont N, Saragosti S, Gresenguet G, Moret $\mathrm{H}$, Jacques J, Longo Jde D, Matta M, et al: Genetic and phenotypic features of blood and genital viral populations of clinically asymptomatic and antiretroviral-treatment-naive clade a human immunodeficiency virus type 1-infected women. J Clin Microbiol 2007, 45:1838-1842.

67. Pillai SK, Good B, Pond SK, Wong JK, Strain MC, Richman DD, Smith DM: Semen-specific genetic characteristics of human immunodeficiency virus type 1 env. J Virol 2005, 79:1734-1742.

68. Poss M, Martin HL, Kreiss JK, Granville L, Chohan B, Nyange P, Mandaliya K Overbaugh J: Diversity in virus populations from genital secretions and peripheral blood from women recently infected with human immunodeficiency virus type 1. J Virol 1995, 69:8118-8122.

69. Zhang L, Rowe L, He T, Chung C, Yu J, Yu W, Talal A, Markowitz M, Ho DD: Compartmentalization of surface envelope glycoprotein of human immunodeficiency virus type 1 during acute and chronic infection. J Virol 2002, 76:9465-9473.

70. Sullivan ST, Mandava U, Evans-Strickfaden T, Lennox JL, Ellerbrock TV, Hart CE: Diversity, divergence, and evolution of cell-free human immunodeficiency virus type 1 in vaginal secretions and blood of chronically infected women: associations with immune status. J Virol 2005, 79:9799-9809.

71. Reece JC, Handley AJ, Anstee EJ, Morrison WA, Crowe SM, Cameron PU: HIV-1 selection by epidermal dendritic cells during transmission across human skin. J Exp Med 1998, 187:1623-1631.

72. Kawamura T, Gulden FO, Sugaya M, McNamara DT, Borris DL, Lederman MM, Orenstein JM, Zimmerman PA, Blauvelt A: R5 HIV productively infects Langerhans cells, and infection levels are regulated by compound CCR5 polymorphisms. Proc Natl Acad Sci USA 2003, 100:8401-8406.

73. Kawamura T, Bruse SE, Abraha A, Sugaya M, Hartley O, Offord RE, Arts EJ, Zimmerman PA, Blauvelt A: PSC-RANTES blocks R5 human immunodeficiency virus infection of Langerhans cells isolated from individuals with a variety of CCR5 diplotypes. J Virol 2004, 78:7602-7609.

74. Tchou I, Misery L, Sabido O, Dezutter-Dambuyant C, Bourlet T, Moja P, Hamzeh H, Peguet-Navarro J, Schmitt D, Genin C: Functional HIV CXCR4 coreceptor on human epithelial Langerhans cells and infection by HIV strain X4. J Leukoc Biol 2001, 70:313-321.

75. lijima N, Linehan MM, Saeland S, Iwasaki A: Vaginal epithelial dendritic cells renew from bone marrow precursors. Proc Natl Acad Sci USA 2007, 104:19061-19066.

76. Zhao X, Deak E, Soderberg K, Linehan M, Spezzano D, Zhu J, Knipe DM, Iwasaki A: Vaginal submucosal dendritic cells, but not Langerhans cells, induce protective Th1 responses to herpes simplex virus-2. J Exp Med 2003, 197:153-162.

77. Ballweber L, Robinson B, Kreger A, Fialkow M, Lentz G, McElrath MJ, Hladik F: Vaginal langerhans cells nonproductively transporting HIV-1 mediate infection of T cells. J Virol 2011, 85:13443-13447

78. de Witte L, Nabatov A, Pion M, Fluitsma D, de Jong MA, de Gruijl T, Piguet $V$, van Kooyk Y, Geijtenbeek TB: Langerin is a natural barrier to HIV-1 transmission by Langerhans cells. Nat Med 2007, 13:367-371.

79. Kawamura T, Kurtz SE, Blauvelt A, Shimada S: The role of Langerhans cells in the sexual transmission of HIV. J Dermatol Sci 2005, 40:147-155.

80. Pope M, Betjes MG, Romani N, Hirmand H, Cameron PU, Hoffman L, Gezelter S, Schuler G, Steinman RM: Conjugates of dendritic cells and 
memory $T$ lymphocytes from skin facilitate productive infection with HIV-1. Cell 1994, 78:389-398.

81. Geijtenbeek TB, Kwon DS, Torensma R, van Vliet SJ, van Duijnhoven GC, Middel J, Cornelissen IL, Nottet HS, KewalRamani VN, Littman DR, et al: DC-SIGN, a dendritic cell-specific HIV-1-binding protein that enhances trans-infection of T cells. Cell 2000, 100:587-597.

82. Cameron PU, Freudenthal PS, Barker JM, Gezelter S, Inaba K, Steinman RM: Dendritic cells exposed to human immunodeficiency virus type-1 transmit a vigorous cytopathic infection to CD4+ T cells. Science 1992, 257:383-387.

83. Frankel SS, Wenig BM, Burke AP, Mannan P, Thompson LD, Abbondanzo SL, Nelson AM, Pope M, Steinman RM: Replication of HIV-1 in dendritic cellderived syncytia at the mucosal surface of the adenoid. Science 1996, 272:115-117.

84. McDonald D, Wu L, Bohks SM, KewalRamani VN, Unutmaz D, Hope TJ: Recruitment of HIV and its receptors to dendritic cell-T cell junctions. Science 2003, 300:1295-1297.

85. Sattentau Q: Avoiding the void: cell-to-cell spread of human viruses. Nat Rev Microbiol 2008, 6:815-826.

86. Mao Y, Wang L, Gu C, Herschhorn A, Xiang SH, Haim H, Yang X, Sodroski J: Subunit organization of the membrane-bound HIV-1 envelope glycoprotein trimer. Nat Struct Mol Biol 2012, 19:893-899.

87. Liao HX, Bonsignori M, Alam SM, McLellan JS, Tomaras GD, Moody MA Kozink DM, Hwang KK, Chen X, Tsao CY, et al: Vaccine induction of antibodies against a structurally heterogeneous site of immune pressure within HIV-1 envelope protein variable regions 1 and 2. Immunity 2013, 38:176-186.

88. Huang W, Eshleman SH, Toma J, Fransen S, Stawiski E, Paxinos EE, Whitcomb JM, Young AM, Donnell D, Mmiro F, et al: Coreceptor tropism in human immunodeficiency virus type 1 subtype $\mathrm{D}$ : high prevalence of CXCR4 tropism and heterogeneous composition of viral populations. J Virol 2007, 81:7885-7893.

89. Baalwa J, Wang S, Parrish NF, Decker JM, Keele BF, Learn GH, Yue L, Ruzagira E, Ssemwanga D, Kamali A, et al: Molecular identification, cloning and characterization of transmitted/founder HIV-1 subtype A, D and A/D infectious molecular clones. Virology 2013, 436:33-48.

90. Ng OT, Laeyendecker O, Redd AD, Munshaw S, Grabowski MK, Paquet AC, Evans MC, Haddad M, Huang W, Robb ML, et al: HIV Type 1 polymerase gene polymorphisms are associated with phenotypic differences in replication capacity and disease progression. J Infect Dis 2013. in press.

91. Baeten JM, Chohan B, Lavreys L, Chohan V, McClelland RS, Certain L, Mandaliya K, Jaoko W, Overbaugh J: HIV-1 subtype D infection is associated with faster disease progression than subtype $A$ in spite of similar plasma HIV-1 loads. J Infect Dis 2007, 195:1177-1180.

92. Provine NM, Puryear WB, Wu X, Overbaugh J, Haigwood NL: The infectious molecular clone and pseudotyped virus models of human immunodeficiency virus type 1 exhibit significant differences in virion composition with only moderate differences in infectivity and inhibition sensitivity. J Virol 2009, 83:9002-9007.

93. Provine NM, Cortez V, Chohan V, Overbaugh J: The neutralization sensitivity of viruses representing human immunodeficiency virus type 1 variants of diverse subtypes from early in infection is dependent on producer cell, as well as characteristics of the specific antibody and envelope variant. Virology 2012, 427:25-33.

94. Binley JM, Ban YE, Crooks ET, Eggink D, Osawa K, Schief WR, Sanders RW: Role of complex carbohydrates in human immunodeficiency virus type 1 infection and resistance to antibody neutralization. J Virol 2010, 84:5637-5655.

95. Raska M, Takahashi K, Czernekova L, Zachova K, Hall S, Moldoveanu Z, Elliott $M C$, Wilson $L$, Brown $R$, Jancova $D$, et al: Glycosylation patterns of HIV-1 gp120 depend on the type of expressing cells and affect antibody recognition. J Biol Chem 2010, 285:20860-20869.

96. Voronin Y, Chohan B, Emerman M, Overbaugh J: Primary isolates of human immunodeficiency virus type 1 are usually dominated by the major variants found in blood. $J$ Virol 2007, 81:10232-10241.

97. Goonetilleke N, Liu MK, Salazar-Gonzalez JF, Ferrari G, Giorgi E, Ganusov W, Keele BF, Learn GH, Turnbull EL, Salazar MG, et al: The first T cell response to transmitted/founder virus contributes to the control of acute viremia in HIV-1 infection. J Exp Med 2009, 206:1253-1272.

98. Shankarappa R, Margolick JB, Gange SJ, Rodrigo AG, Upchurch D, Farzadegan H, Gupta P, Rinaldo CR, Learn GH, He X, et al: Consistent viral evolutionary changes associated with the progression of human immunodeficiency virus type 1 infection. J Virol 1999, 73:10489-10502.

99. Wawer MJ, Sewankambo NK, Serwadda D, Quinn TC, Paxton LA, Kiwanuka N, Wabwire-Mangen F, Li C, Lutalo T, Nalugoda F, et al: Control of sexually transmitted diseases for AIDS prevention in Uganda: a randomised community trial. Rakai Project Study Group. Lancet 1999, 353:525-535.

100. Wawer MJ, Gray RH, Sewankambo NK, Serwadda D, Paxton L, Berkley S, McNairn D, Wabwire-Mangen F, Li C, Nalugoda F, et al: A randomized, community trial of intensive sexually transmitted disease control for AIDS prevention, Rakai, Uganda. AIDS 1998, 12:1211-1225.

101. Wawer MJ, Gray RH, Sewankambo NK, Serwadda D, Li X, Laeyendecker O, Kiwanuka N, Kigozi G, Kiddugavu M, Lutalo T, et al: Rates of HIV-1 transmission per coital act, by stage of HIV-1 infection, in Rakai, Uganda. $J$ Infect Dis 2005, 191:1403-1409.

102. Kiwanuka N, Laeyendecker O, Quinn TC, Wawer MJ, Shepherd J, Robb M Kigozi G, Kagaayi J, Serwadda D, Makumbi FE, et al: HIV-1 subtypes and differences in heterosexual HIV transmission among HIV-discordant couples in Rakai, Uganda. AIDS 2009, 23:2479-2484.

103. Dudley DM, Gao Y, Nelson KN, Henry KR, Nankya I, Gibson RM, Arts EJ: A novel yeast-based recombination method to clone and propagate diverse HIV-1 isolates. Biotechniques 2009, 46:458-467.

104. Swanson CM, Malim MH: SnapShot: HIV-1 proteins. Cell 2008, 133:742. 742 e741.

105. Kimpton J, Emerman M: Detection of replication-competent and pseudotyped human immunodeficiency virus with a sensitive cell line on the basis of activation of an integrated beta-galactosidase gene. J Virol 1992, 66:2232-2239.

106. Wei X, Decker JM, Liu H, Zhang Z, Arani RB, Kilby JM, Saag MS, Wu X, Shaw $G M$, Kappes JC: Emergence of resistant human immunodeficiency virus type 1 in patients receiving fusion inhibitor (T-20) monotherapy. Antimicrob Agents Chemother 2002, 46:1896-1905.

107. Bjorndal A, Deng H, Jansson M, Fiore JR, Colognesi C, Karlsson A, Albert J, Scarlatti G, Littman DR, Fenyo EM: Coreceptor usage of primary human immunodeficiency virus type 1 isolates varies according to biological phenotype. J Virol 1997, 71:7478-7487.

108. de Almeida MC, Silva AC, Barral A, Barral Netto M: A simple method for human peripheral blood monocyte isolation. Mem Inst Oswaldo Cruz 2000, 95:221-223.

109. Wiley RD, Gummuluru S: Immature dendritic cell-derived exosomes can mediate HIV-1 trans infection. Proc Natl Acad Sci USA 2006, 103:738-743.

110. Sagar M, Akiyama H, Etemad B, Ramirez N, Freitas I, Gummuluru S: Transmembrane domain membrane proximal external region but not surface unit-directed broadly neutralizing HIV-1 antibodies can restrict dendritic cell-mediated HIV-1 Trans-infection. J Infect Dis 2012, 205:1248-1257.

111. Rousseau CM, Nduati RW, Richardson BA, John-Stewart GC, Mbori-Ngacha DA, Kreiss JK, Overbaugh J: Association of levels of HIV-1-infected breast milk cells and risk of mother-to-child transmission. J Infect Dis 2004, 190:1880-1888.

112. Rousseau CM, Nduati RW, Richardson BA, Steele MS, John-Stewart GC, Mbori-Ngacha DA, Kreiss JK, Overbaugh J: Longitudinal analysis of human immunodeficiency virus type 1 RNA in breast milk and of its relationship to infant infection and maternal disease. J Infect Dis 2003, 187:741-747.

\section{doi:10.1186/1742-4690-10-162}

Cite this article as: Pena-Cruz et al:: HIV- 1 envelope replication and $\alpha 4 \beta 7$ utilization among newly infected subjects and their corresponding heterosexual partners. Retrovirology 2013 10:162. 